
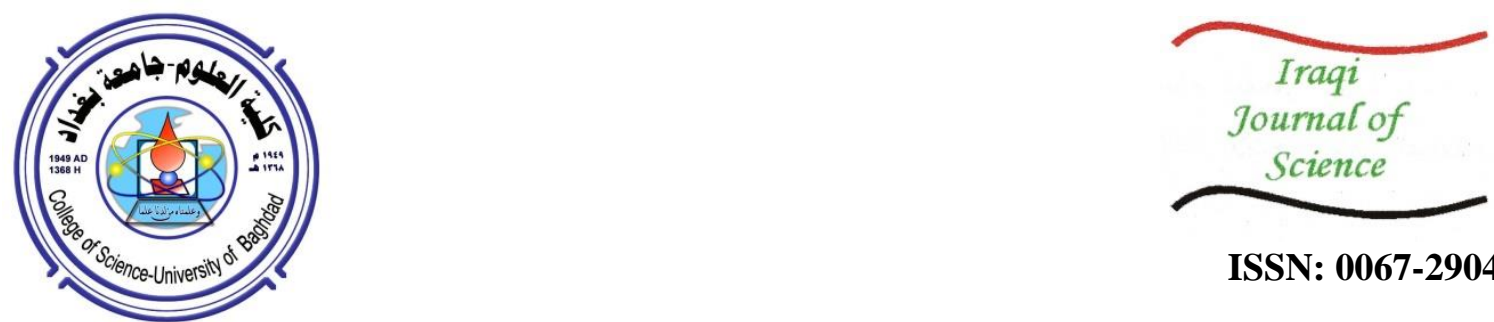

ISSN: 0067-2904

\title{
Organic Geochemistry and Thermal Maturity Assessment of Cretaceous Balambo Formation from Selected Sites, Kurdistan, NE Iraq
}

\author{
Razawa Hamarashid A. Sarraj", Ibrahim Mohammed J. Mohialdeen \\ Department of Geology, College of Science, University of Sulaimani, Kurdistan, Iraq
}

Received: $18 / 3 / 2020$

Accepted: 2/6/2020

\begin{abstract}
The Cretaceous Balambo Formation from three sections in Kurdistan Region of Northern Iraq was studied. The selected sections are located in the Zagros Fold Thrust Belt. Eleven rock samples were analyzed by means of the organic geochemical method, Bitumen extraction method, and gas chromatography/mass spectrometry to determine the bitumen and hydrocarbon content, kerogen types, origin of organic matter, thermal maturity level, and depositional environment. The analyzed samples are considered to have an excellent potential in Baranan-1.G1 and Sazan sections, with poor to fair potential in Baraw section. The Baranan-1.G1 source rocks are of type II kerogen (oil prone), whereas Sazan and Baraw samples are of type II/III (oil/gas prone). Detailed distribution analysis of biomarkers such as normal alkane, isoprenoids, sterane and terpane was performed on saturated hydrocarbons. The mode of $n$-alkanes and isoprenoids distribution in all analyzed samples is similar, with a unimodal distribution that indicates non-biodegraded hydrocarbons, with the same range of alkane compounds between $\mathrm{C}_{13-} \mathrm{C}_{34}$ alkanes. The results of $n-\mathrm{C}_{17}$, pristane, $n-\mathrm{C}_{18}$ and phytane, and regular steranes show that the source rocks of Balambo Formation in Baranan-1.G1 are mainly rich with algal marine organic matter deposited under a reducing environment, while Baraw and Sazan sections are composed of mixed marine organic matter that refers to terrestrial land plants input deposited under reducing anoxic/dysoxic environments. Thermal maturation appraisal is deduced from Pristane $/ n-\mathrm{C}_{17}$ versus Phytane $/ n-\mathrm{C}_{18}$ diagram, Carbon Preference Index (CPI), $\mathrm{C}_{29} \beta \beta /(\beta \beta+\alpha \alpha), \mathrm{C}_{29} 20 \mathrm{~S} /$ $(20 \mathrm{~S}+20 \mathrm{R}), \mathrm{C}_{32} 22 \mathrm{~S} /(22 \mathrm{~S}+22 \mathrm{R})$, and $\mathrm{Ts} /(\mathrm{Ts}+\mathrm{Tm})$. All these parameters indicate that the analyzed samples are mature and have entered the oil window (early to peak oil window). Biomarker ratios of $\mathrm{C}_{22} / \mathrm{C}_{21}, \mathrm{C}_{24} / \mathrm{C}_{23}$ and $\mathrm{C}_{26} / \mathrm{C}_{25}, \mathrm{C}_{31} \mathrm{R} / \mathrm{C}_{30} \mathrm{H}$ show that the Balambo Formation is composed mostly of carbonates with less shale beds.
\end{abstract}

Keywords: Balambo Formation, Biomarkers, Cretaceous, Iraq, Kurdistan.

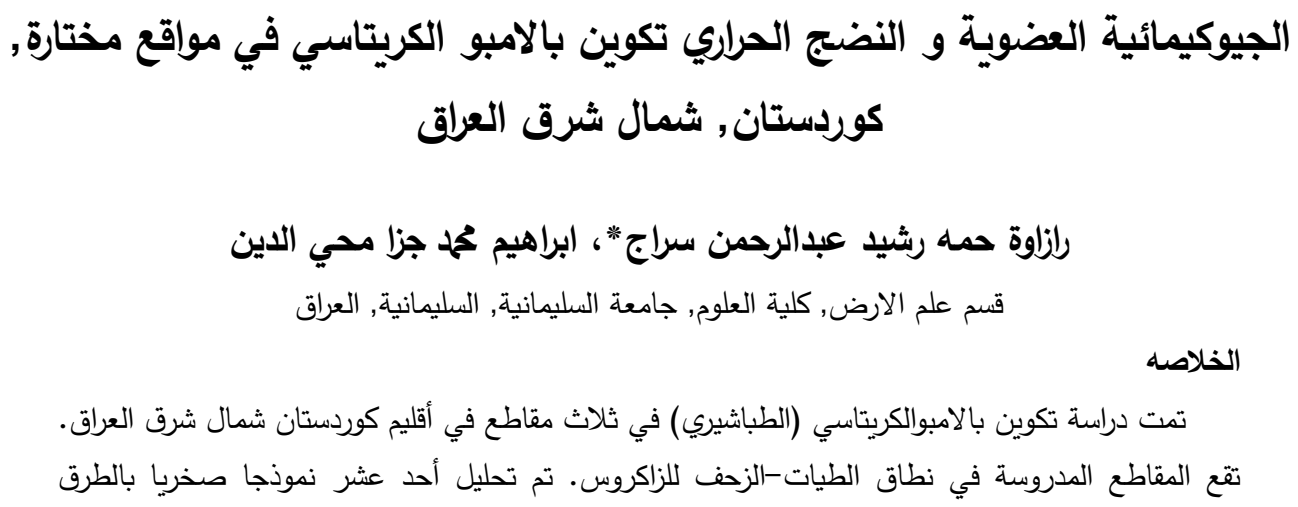

*Email: razawa.abdulrahman@univsul.edu.iq 


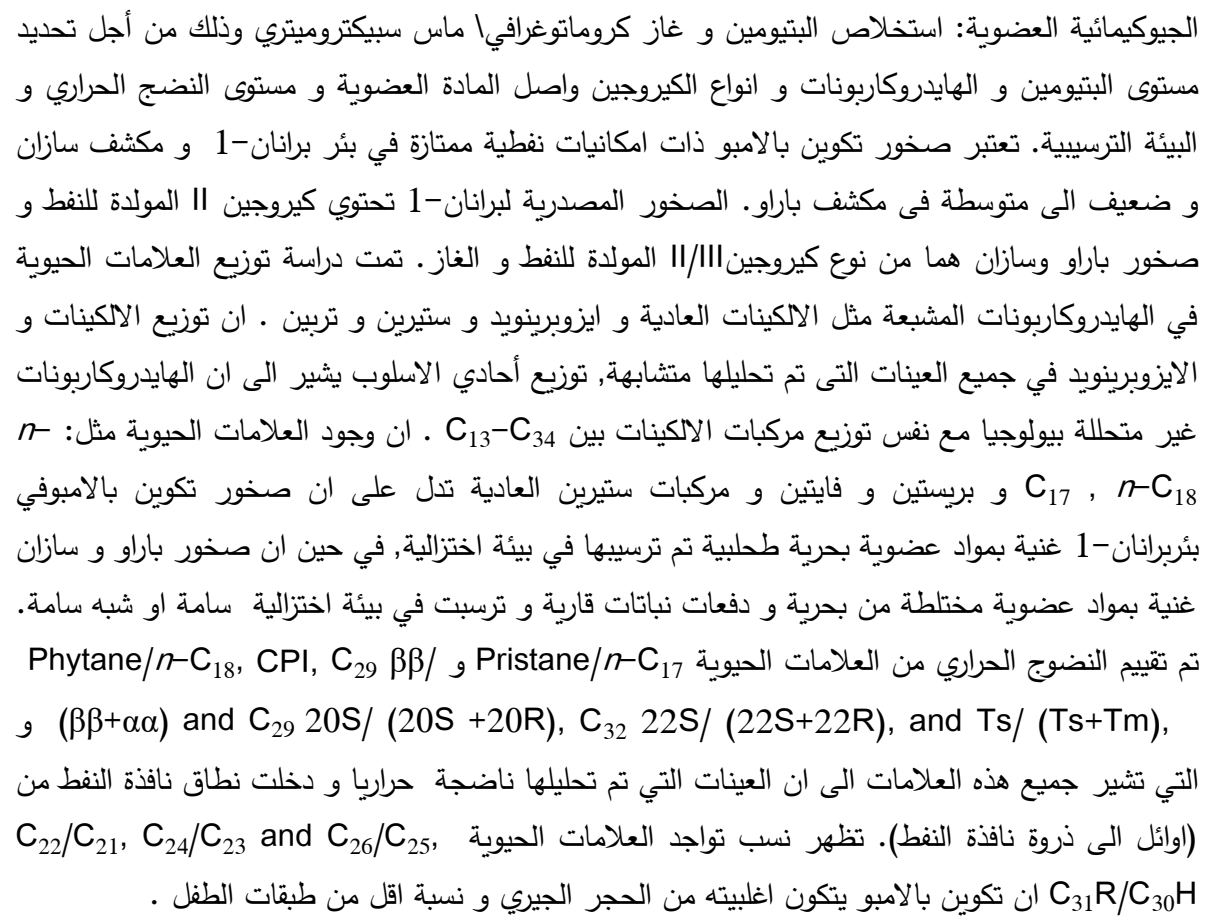

\section{Introduction}

Most of the Cretaceous rock units within the petroleum system of Iraq represent reservoirs, such as Qamchuqa, Dokan, Kometan, and Shiranish formations [1, 2]. However, there are few sequences that may be good source rocks (e.g. Ratawi, Sulaiy, and Balambo formations) (Figure-1). Source rock assessment and petroleum generation potentiality of Cretaceous sediments have been conducted by several researchers $[3,4,5]$. The Balambo Formation is one of the Cretaceous carbonate sequences with narrow geographic distribution and long geologic age (Figure-1). The Balambo Formation was first described in 1947 by Wetzel [6] from Sirwan Valley near the boundary between the Imbricated and High Folded Zones of northeastern Iraq. According to the lithology and age, it is divided into two units of the Lower Balambo (Valanginian- middle Albian), composed of thin bedded ammonite- rich limestone with intercalations of olive- green marls and dark blue shales, and the upper Balambo (Late Albian-Turonian), composed of thin bedded globigerinal, passing downward to radiolarian limestone $[6,7]$. It passes westwards and northwestwards from the type area of the Balambo Formation (Sirwan River, Halabja, etc.) The basal sediments of the formation laterally and gradationally change into neritic sediments of the Sarmord Formation and iron-rich oolitic and arenaceous beds at the base Garagu Formation found in some areas [6]. The middle portion of Balambo Formation (HauterivianAlbian) laterally passes westwards and northwestwards, through Sarmord Formation into massive, neritic limestone of Qamchuqa Formation [6, 8, 9] (Figure-1). 




Figure 1- Megasequence AP8 showing Balambo Formation equivalents in Iraq and NE Jordan [10]

The principal source rocks responsible for charging most of Iraqi reservoirs were deposited during Late Jurassic to Early-Middle Cretaceous [11], including Balambo Formation that is considered as good potential source rock [12]. Al-Sharhan and Nairn [11] reported that the hydrocarbon began generating in the lower part of Balambo Formation some $15 \mathrm{Ma}$ ago, and the oil migrated horizontally under the Sarmord seal and was trapped in reservoirs in the Kirkuk, Jambour and Khabaz fields. The formation was also considered as fair to good source rock, with kerogen type II/III of highly oil prone and oil- and gas prone [11]. Mahdi [5] determined the depositional conditions of the formation from several oil fields in northern Iraq as distal suboxic to anoxic basin. However, another work [13] considered the Balambo Formation as of little potentiality in northern Iraq. Recently, Sarraj and Mohialdeen [14] studied the formation in three sections in Kurdistan Region and they concluded that the formation is deposited in deep marine-bathyal environment with anoxic to suboxic conditions.

The main purpose of this paper is to geochemically study the Balambo Formation from three selected sections (two outcrops and one well) in order to determine the type and origin of the organic matter and appraising the thermal maturity of these rocks. For achieving this purpose, an organic geochemical analysis was conducted.

\section{Geological setting}

The Berriasian-Aptian succession in Iraq is represented by many formations, most of which are occurring on the platform area on both the stable shelf (south and central areas) and unstable shelf (northern areas) [6, 11]. During the Late Tithonian - Cenomanian, the Southern Neo-Tethys was opened. This opening was formed because of the breakup of Gondwana. Deposition of radiolarian chert began in the Tithonian time in southeast Turkey (Karadut Complex) and northeast Iraq (Qulqula Group) [10]. The opening of the Southern Neo-Tethys led to the drifting away of a narrow microcontinent; a new passive margin was formed along the NE margin of the Arabian Plate [13]. During Berriasian - Albian subsidence, carbonate platform margins aggraded and locally prograded into the Balambo-Garau Basin; up to $1500 \mathrm{~m}$ of carbonates with significant Berriasian- Hauterivian 
and Albian siliciclastic intervals were deposited [1, 10].

The studied area is located in the Zagros Fold-Thrust Belt (ZFTB) from Kurdistan region , northeastern Iraq (Figure-2). The ZFTB extends approximately $2000 \mathrm{Km}$ from the Strait of Hormuz southwest Iran to the Kurdistan Region (north Iraq) and southeast Turkey. It is formed from the Zagros Orogeny due to collision between the Arabian and Eurasian plates [15, 16]. The ZFTB is located on the boundary of the Arabian and Eurasian plates, and causes the closure of the Neo-Tethys Ocean. The ZFTB consists of a foreland fold zone and a thrust zone, oriented SE to NW. It consists of suture or thrust along with imbricated, high folded, and low folded zones of Iraq [17, 18]. The ZFTB holds $49 \%$ of the global fold-thrust belt hydrocarbons [16]. The Zagros Fold Belt is estimated to contain about 4.5 billion barrels of Iraq's 153 billion barrels of oil reserves, making Iraq the fourth largest oil reserve in the world $[19,12]$.

3. Stratigraphy of the studied sections

The detailed description of the Balambo Formation in the three selected sections is as follows (Figures-(2-4):

\subsection{Baraw section}

The Baraw section is located about $24 \mathrm{~km}$ northeast of Sulaimani city with coordinates of $35^{\circ} 36^{\prime}$ $17^{\prime \prime} \mathrm{N}$ and $45^{\circ} 41^{\prime} 26^{\prime \prime} \mathrm{E}$ (Figure-2). The thickness of Balambo Formation in Baraw section is about $234 \mathrm{~m}$. It is composed of alternations of grey to dark colors, medium to thick bedded limestone with organic-rich shale, thin bedded chert, and marlstone at the base (Figure- 3 a ). The carbonate layers are characterized by the presence of ammonite (Figure- 3 b), carbonate concretion, and liesigang ring structures. The underlying formation is Late Jurassic-Early Cretaceous Chia Gara Formation, and the overlying formation is not clear and covered (mostly Kometan Formation) (Figure-1). Based on the field description of Bellen et al. [6], this sequence represents both the lower and upper parts of Balambo Formation.

\subsection{Sazan Section}

The Sazan section is located about $72 \mathrm{~km}$ southeast of Sulaimaniya city with coordinates of $35^{\circ} 7^{\prime}$ $14^{\prime \prime} \mathrm{N}$ and $46^{\circ} 1^{\prime} 38^{\prime \prime} \mathrm{E}$ (Figure-2). The thickness of Balambo Formation is sixty- three meters, situated in a highly folded and faulted area in northern Iraq. The study sections were carefully selected to avoid repeating due to intensive folding in the region. The section is characterized by light grey limestone beds containing organic rich bands with shale layers in the middle and upper parts (Figure-4 a). The carbonate layers are characterized by the presence of ammonite impressions (Figure- 4b), lamination, carbonate concretion, and liesigang ring structures. Chia Gara Formation is underlying the Balambo Formation in this section. However, the overlying unit is unclear and not recognized. Balambo Formation of Sazan section represents both parts of the sequence [6].

\subsection{Baranan-1.G1 (Bn-1) section}

This subsurface section was taken from a recently drilled well by TOTAL Company, which reaches to Lower Balambo Formation. The well is about $30 \mathrm{~km}$ southeast of Sulaimaniya with coordinates of $35^{\circ} 17^{\prime} 54.6^{\prime \prime} \mathrm{N}$ and $45^{\circ} 32^{\prime} 08.4^{\prime \prime} \mathrm{E}$ (Figure-2). Both parts of Balambo Formation are recognized and determined. The Upper Balambo Formation is of 3831 to $4172 \mathrm{~m}$ depth, with thickness of about $341 \mathrm{~m}$, being composed of limestone, marlstone, and argillaceous limestone. The lower Balambo Formation starts from depth 4290 to $4355 \mathrm{~m}$., which is composed of marlstone and limestone with traces of chert (Figure-5). The Gamma Ray log (GR) shows a high GR peak at depth $3832 \mathrm{~m}$ from the upper part of Upper Balambo Formation which could be a thin layer of shale, and also at the depth interval 4313.5-4314.5m from lower Balambo Formation. The high GR could be a thin layer of shale, while the remaining layers are homogenous throughout the section (Figure-5). 




Figure 2-Location of the studied Baraw, Bn-1 and Sazan sections, Kurdistan Region, NE Iraq. 


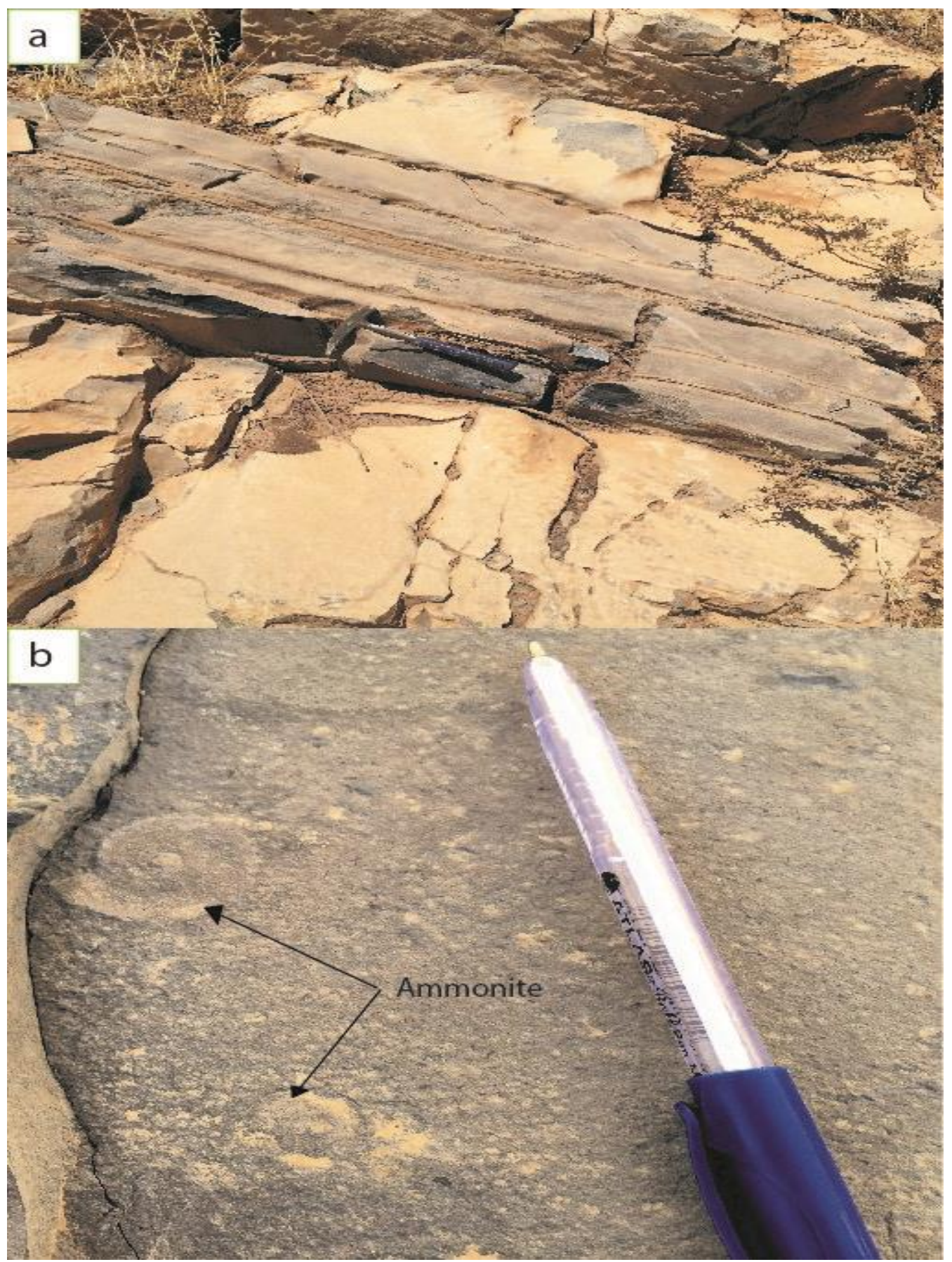

Figure 3- Field photographs of Balambo Formation in Baraw section: a- The lithology of the Balambo Formation, b- Ammonite impression. 




Figure 4- Field photographs of Balambo Formation in Sazan section: a- The Balambo Formation lithology, b- Ammonite macrofossil.. 


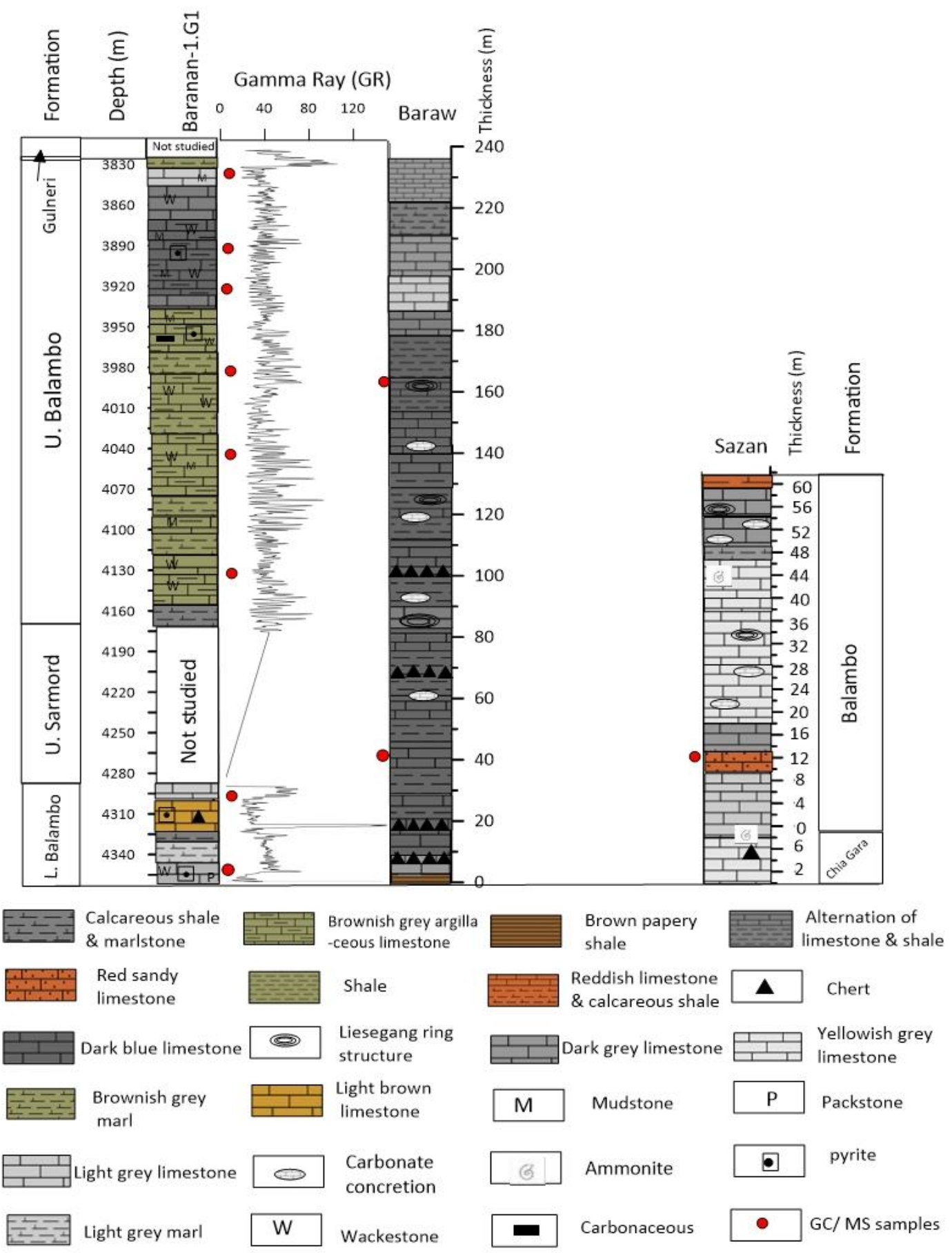

Figure 5- Stratigraphic column of Balambo Formation in the Baraw, Bn-1 and Sazan sections, Kurdistan Region, NE Iraq

\section{Samples and experimental methods}

Ninety- nine rock samples of Balambo Formation were taken from three sections. The Bn-1 samples were provided from the store of the Ministry of Natural Resources in Erbil Governorate. Eleven rock samples were subjected to organic geochemical techniques; bitumen extraction, gas chromatography (GC), and gas chromatography-mass spectrometry (GC/MS). The GC/MS analysis was carried out at the organic geochemistry laboratory in the Geology Department at the University of Malaya, Malaysia.

Approximately $30 \mathrm{~g}$ of powdered sample was Soxhlet extracted for 72 hours using an azeotropic mixture of dichloromethane and methanol (93:7) [20].The asphaltene precipitation was a chieved using the ASTM procedure (ASTM D2007-80). Th e accurate volume of the extracted 
bitumen was measured into a test tube. About 20 times that volume of $n$-heptane was added to the test tube, making the ratio of $n$-heptane to extracted bitumen about 95:5. The test tubes were slotted in a tabletop centrifuge and the motor was spun for about 20 minutes. The maltene (liquid at the top of the tube after centrifugation, containing aliphatic, aromatic and NSO) was collected. These steps were repeated until the supernatant became colorless. The maltene was separated into saturated hydrocarbon, aromatic hydrocarbon, and NSO compound fractions by liquid column chromatography. A chromatographic column $(30 \times 0.72 \mathrm{~cm})$ was packed with silica gel of $60-120$ mesh that was activated for 2 hours at $120{ }^{\circ} \mathrm{C}$ and capped with alumina. The column was then developed with solvents of increasing polarity, i.e. light petroleum $(100 \mathrm{ml})$, dichloromethane $(.100 \mathrm{ml})$ and methanol $(50 \mathrm{ml})$. The eluates were collected in separate $250 \mathrm{ml}$ round-bottom flasks. The solvent was later reduced using a Buchi apparatus and the weights of the eluates were recorded.

The GC and GC/ MS were used to analyze the aliphatic hydrocarbons that predominantly consist of saturated hydrocarbons. The gas chromatography analysis was performed using HP-5MS column with a temperature programmed at 40 to $300{ }^{\circ} \mathrm{C}$ with a rate of $4{ }^{\circ} \mathrm{C} / \mathrm{min}$, which was then held for $30 \mathrm{~min}$ at $300{ }^{\circ} \mathrm{C}$. The aliphatic fractions were subsequently analyzed using an Agilent 5975B inert MSD mass spectrometer with a gas chromatograph attached directly to the ion source (70 eV ionization voltage, $100 \mathrm{~mA}$ filament emission current, $230{ }^{\circ} \mathrm{C}$ interface temperature). Selected peaks (e.g. $n$ alkanes, hopanes, tricyclic terpanes, and steranes) were identified based on their retention times and comparison with identifications reported by previous researchers [20, 21, 22]. The selected ion monitoring capabilities of the data acquisition system permitted specific ions to be monitored, such as $n$-alkanes $(\mathrm{m} / \mathrm{z} \mathrm{85})$, triterpanes $(\mathrm{m} / \mathrm{z} 191)$, and steranes $(\mathrm{m} / \mathrm{z} 217)$ of saturated hydrocarbon ratios, as presented by previous works [21,22]. Terpane and sterane distributions were quantified by measuring peak heights in the $m / z 191$ and $m / z 217$ chromatograms, respectively.

\section{Results}

\subsection{Organic matter richness}

The amount of extractable organic matter (EOM) together with the relative proportions of saturated, aromatic fractions, and nitrogen, sulphur, and oxygen (NSO) compounds were calculated and tabulated (Table-1). The extract yields expressed as part per million (ppm) are cross plotted against TOC (wt. \%) in Figure-6. Based on the classification by Peters and Cassa [23], the samples from Baraw possess a poor to fair value for the bitumen/EOM and hydrocarbon (HC) content. The samples from Bn-1 and Sazan sections generally possess excellent $\mathrm{HC}$ content with a value of $>4,000$ ppm (Table- 1, Figure- 6).

The EOM values of the Baraw samples are 226 and $745 \mathrm{ppm}$, that can be considered as poor to fair source rocks, while the EOM yield values of Bn-1 section ranged from 10,690 to 16,918 ppm, and that of Sazan sample was 20,221 ppm. This indicates that the latter two sections are organic- rich sediments and excellent source rocks (Figure- 6). The percentages of the maltene and asphaltene fractions are shown in Table-1. Maltene represents major fractions of the analyzed samples. The maltene fractions compose a proportion of $50.5 \%-66.1 \%$, whereas asphaltene fractions range from $33.9 \%$ to $49.5 \%$. However, the two Baraw samples show the absence of maltane and asphaltenes. The normal procedure was not applied for these two samples because they possessed a low amount of EOM (0.0032 and 0.0108). The most important fraction to be analyzed is the saturated organic matter. Thus, the EOM was first precipitated to obtain asphaltene and maltene, then $80 \%$ of EOM was separated (directly with no asphaltenes precipitation analysis) to ensure sufficient saturation. For the remaining (20\%) of the EOM, the normal procedure was used, but there was a very low amount of about 0.000001 or lower.

The saturated and NSO components represent major fractions of the analyzed samples. The saturated fractions and NSO compounds are ranging from $32.3 \%$ to $40.2 \%$ and $30.0 \%$ to $46.1 \%$, respectively. The aromatic fractions range from $18.3 \%$ to $33.4 \%$. (Table- 1, Figure- 7). 




Figure 6- Relationship between Total Organic Carbon (TOC wt. \%) content versus Extracted Bitumen (ppm) of Balambo Formation in the three sections, Kurdistan, Iraq.



Figure 7- Ternary diagram of saturated, aromatic hydrocarbons and NSOcomponents for the studied samples of Balambo Formation. 
Table 1- Extractable organic matter (EOM) yield and asphaltene precipitation data of Balambo Formation in Baraw, Bn-1 and Sazan sections, NE Iraq

\begin{tabular}{|c|c|c|c|c|c|c|c|c|c|c|c|c|}
\hline : & 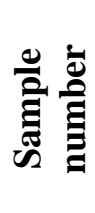 & 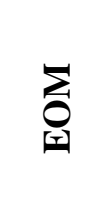 & 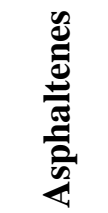 & 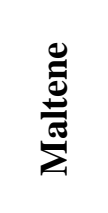 & $\sum_{\text {ఏ되 }}^{\sum}$ &  & \begin{tabular}{l}
0 \\
$E$ \\
\multirow{2}{*}{}
\end{tabular} & $\begin{array}{l}0 \\
0 \\
2\end{array}$ & $\begin{array}{l}0 \\
0 \\
\not \\
Z\end{array}$ & 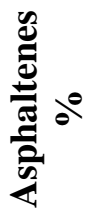 & 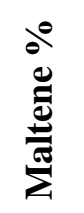 & $\begin{array}{l}\dot{8} \\
\dot{\theta} \\
\dot{E}\end{array}$ \\
\hline Baraw & 14 & 0.0032 & 0 & 0 & 226 & 141 & 33.3 & 26.7 & 40 & 0 & 0 & 1.97 \\
\hline Baraw & 28 & 0.0108 & 0 & 0 & 745 & 359 & 40.2 & 20.7 & 39.1 & 0 & 0 & 2.09 \\
\hline Bn-1 & 1 & 0.2373 & 0.0814 & 0.1519 & 16918 & 5254 & 39.8 & 19.8 & 40.3 & 34.9 & 65.1 & 2.92 \\
\hline Bn-1 & 5 & 0.2005 & 0.0983 & 0.1002 & 16344 & 4932 & 32.3 & 21.6 & 46.1 & 49.5 & 50.5 & 6.6 \\
\hline Bn-1 & 7 & 0.1664 & 0.0595 & 0.1039 & 10690 & 4259 & 32.6 & 25.3 & 42.1 & 36.4 & 63.6 & 9.86 \\
\hline Bn-1 & 11 & 0.202 & 0.0911 & 0.11 & 13142 & 4502 & 36.3 & 27.3 & 36.3 & 45.3 & 54.7 & 4.08 \\
\hline Bn-1 & 15 & 0.1705 & 0.057 & 0.1112 & 12162 & 5115 & 30 & 33.4 & 36.6 & 33.9 & 66.1 & 6.09 \\
\hline Bn-1 & 21 & 0.2074 & 0.0771 & 0.1293 & 13554 & 4202 & 38.3 & 24.7 & 37 & 37.4 & 62.6 & 6.14 \\
\hline Bn-1 & 25 & 0.2191 & 0.08 & 0.12 & 13146 & 4596 & 36.1 & 22.7 & 41.2 & 40 & 60 & 2.46 \\
\hline Bn-1 & 29 & 0.2 & 0.0873 & 0.11 & 11001 & 4505 & 36.3 & 18.3 & 45.4 & 44.2 & 55.8 & 1.69 \\
\hline Sazan & 14 & 0.3033 & 0.1092 & 0.1911 & 20221 & 6620 & 39.6 & 30.3 & 30 & 36.4 & 63.6 & 1.81 \\
\hline
\end{tabular}

EOM: Extractable organic matter (EOM) yield and Asphaltenes precipitation, TOC wt.\%: Total organic carbon, ARO: Aromatic hydrocarbons, NSO: Nitrogen, Sulfur, Oxygen components, HCs: Hydrocarbon fractions (Saturated + Aromatic), ppm: part per million.

\subsection{Molecular composition}

The biomarkers distribution may provide information about organic matter facies and depositional environment, origin, kerogen type and maturation [24]. In this study, detailed biomarkers distribution within the Balambo Formation, such as normal alkane, isoprenoids, steranes and terpanes were performed on saturated hydrocarbons (Table-2, Appendix) and their traces, recorded on $\mathrm{m} / \mathrm{z} 85, \mathrm{~m} / \mathrm{z}$ 191 and $m / z, 217$ mass fragmentograms, respectively (Figures- 8-10).

\subsection{1. $n$-alkanes and isoprenoids}

The saturated gas chromatograms of the analyzed Balambo extracts reveal a full suite of saturated hydrocarbons between $\mathrm{C}_{13}-\mathrm{C}_{34} n$-alkanes and isoprenoids pristane (Pr) and Phytane (Ph) (Figure-8). The $n$-alkane patterns are dominated by short $\left(n-\mathrm{C}_{15}-n-\mathrm{C}_{20}\right)$ to middle $\left(n-\mathrm{C}_{21}-n\right.$ - $\left.\mathrm{C}_{25}\right)$ chain $n$ alkanes with the presence of certain waxy alkanes $\left(+n-\mathrm{C}_{23}\right)$, which caused moderate Carbon Preference Index $(\mathrm{CPI})$ values $(\mathrm{CPI}<1.16)$.

The abundant source of pristane $\left(\mathrm{C}_{19}\right)$ and phytane $\left(\mathrm{C}_{20}\right)$ is the phytal side chains of chlorophyll in photomorphic organisms and bacteriochlorophyll in purple sulphur bacteria [21,25]. The modes of $n$ alkane and isoprenoids distributions in all the analyzed samples are similar. The results showed a unimodal distribution, non-biodegraded hydrocarbons, and marine source organic matter enriched with algal and/or bacterial organisms, with the same range of alkane compounds; between $\mathrm{C}_{13}-\mathrm{C}_{34} n$ alkanes (Figure-8).

The CPI is a mathematical expression of the odd over even predominance between $n$ - $\mathrm{C}_{24}$ and $n$ $\mathrm{C}_{34}$ [21, 26]. A CPI value higher than 1 indicates thermally mature source rocks, with CPI equal to or lower than 1 may arise from a predominance of marine input and /or thermal maturation, while high CPI indicates low maturity [27]. The CPI values of the analyzed samples range from 0.93-1.16. The majority of the samples have CPI higher than 1. except Sazan sample, sample no.14 of Baraw, and no. 25 of Bn-1, which show values lower than or around 1 (Table- 2).

The most important acyclic isoprenoids in hydrocarbons are Pristane ( $\mathrm{Pr})$ and Phytane (Ph) [25], 
both reflecting the paleoenvironmental conditions of source rocks and are considered as indicators for the redox conditions during sedimentation and diagenesis $[28,29]$. The $\mathrm{Pr} / \mathrm{Ph}$ ratio was calculated based on $\mathrm{m} / z \quad 85$ mass fragmentograms of saturated hydrocarbon fractions. The $\mathrm{Pr} / \mathrm{Ph}$ ratio increases with increasing thermal maturity. The analyzed samples of Bn-1 and Sazan sections show higher $\mathrm{Ph}$ content than that of $\mathrm{Pr}$, causing a low $\mathrm{Pr} / \mathrm{Ph}$ ratio of 0.37 to 0.60 , whereas the Sazan sample has a $\mathrm{Pr} / \mathrm{Ph}$ ratio of 0.91 . The two Baraw samples show higher $\mathrm{Pr}$ content than that of $\mathrm{Ph}$, causing a $\mathrm{Pr} / \mathrm{Ph}$ ratio of 1.10 (Table -2). According to Peters and Moldowan [30], the terrestrial plants have a high $\mathrm{Pr} / \mathrm{Ph}$ ratio of $>3$ which indicate oxidizing conditions, while low values of $\mathrm{Pr} / \mathrm{Ph}(<1)$ indicate anoxic conditions and values between 1 and 3 indicate intermediate (Suboxic) conditions. From this point of view, the Balambo Formation in Bn-1 and Sazan sections show anoxic conditions, while Baraw samples indicate suboxic condition.

The ratio of $\mathrm{Pr} / n-\mathrm{C}_{17}$ is useful for differentiating organic matter of swamp environment (higher than1.0) from those formed under marine environment (lower than 0.5). However, this ratio is affected by maturity, as well as biodegradation [31]. The ratio of $\mathrm{Pr} / n-\mathrm{C}_{17}$ in all $\mathrm{Bn}-1$ samples range from 0.17 to 0.32 (i. e. < 0.5 ) indicating a marine environment, while that of Baraw and Sazan samples range from 0.51 to 0.57 , indicating dysoxic condition (Figure-11). The $\mathrm{Ph} / n-\mathrm{C}_{18}$ ratio is higher than that of $\mathrm{Pr} / n-\mathrm{C}_{17}$ in all samples of Bn-1 and Sazan sections, but not in the two Baraw samples (Table- 2). A cross plot of $\mathrm{Pr} / n-\mathrm{C}_{17}$ and $\mathrm{Ph} / n-\mathrm{C}_{18}$ that was proposed by Shanmugam [32] provides good information about organic matter type, organic facies, biodegradation, and maturation level. All the analyzed samples are mature and no obvious biodegradation occurred (Figure-11).

The Terrigenous/ Aquatic Ratio (TAR) was determined for the Balambo Formation samples using the equation $\left(\mathrm{C}_{27}+\mathrm{C}_{29}+\mathrm{C}_{31}\right) /\left(\mathrm{C}_{15}+\mathrm{C}_{17}+\mathrm{C}_{19}\right)$. The results ranged from 0.15 to1.07 (Table -2$)$.

\subsubsection{Terpane biomarkers}

Many terpanes in petroleum originate from bacterial prokaryotic membrane lipids [24]. These bacterial terpanes include a series of several homologues including acyclic, bicyclic, tricyclic, tetracyclic and pentacyclic compounds [21]. The tricyclic terpanes extends from $C_{19}$ to at least $C_{54}$ because of their isoprenoid side chains [33]. Tetracyclic terpane from $\mathrm{C}_{24}$ to $\mathrm{C}_{27}$ appeared to be more resistant to biodegradation than the hopanes, which are pentacyclic terpanes that extend from $\mathrm{C}_{27}$ to $\mathrm{C}_{35}$, originating from precursors bacterial membranes [21].

The C-ring from $\mathrm{C}_{20}-\mathrm{C}_{24}$ tri and the tetracyclic compounds can be detected at $\mathrm{m} / z 191$ mass chromatograms. Most of the analyzed samples have $\mathrm{C}_{23}$ of larger peak than the others except samples 28 of Baraw section and 29 of $\mathrm{Bn}-1$ section (Figure- 9). The relatively low $\mathrm{C}_{29} / \mathrm{C}_{30}$ (Table -2 ) is consistent with clay-rich rocks (e.g. shale). $\mathrm{C}_{29} / \mathrm{C}_{30}$ ratio of higher than 1 is commonly associated with carbonate source rocks, but this is not always the case [34]. The enhanced $\mathrm{C}_{29}$-norhopane input may also be associated with land plant input [35]. In this study, the $\mathrm{C}_{29} / \mathrm{C}_{30}$ ratio ranges from 0.81 to 1.13 , this indicates a mixed carbonate and clay rock (shale).

The homohopane series $\left(\mathrm{C}_{31}-\mathrm{C}_{34}\right)$ of this study is decreasing toward $\mathrm{C}_{34}$. The absence or minor $\mathrm{C}_{34}$ and $\mathrm{C}_{35}$ (Gammacerane) indicates samples of normal salinity [36]. The Oleanane compound is not detected in the analyzed samples (Figure-9).

\subsubsection{Sterane biomarkers}

The occurrence of C27-C29 regular steranes indicates the contribution of eukaryotic organisms [37]. The sterane and diasterane biomarkers of the analyzed Balambo samples, as detected in the $\mathrm{m} / \mathrm{z}$ 217 fragmentograms, are calculated. Nearly all the analyzed samples are similar $\left(C_{27}>C_{29}>C_{28}\right)$, except sample no. 25 of the $\mathrm{Bn}-1$ section which has the order of $\mathrm{C}_{29}>\mathrm{C}_{27}>\mathrm{C}_{28}$ (Table- 2). The ratio of $\mathrm{C}_{27} / \mathrm{C}_{29}$ is also determined, where the results show a range of $1.02-1.55$; only the sample no. 25 of Bn-1 section has a lowest value (0.80). 


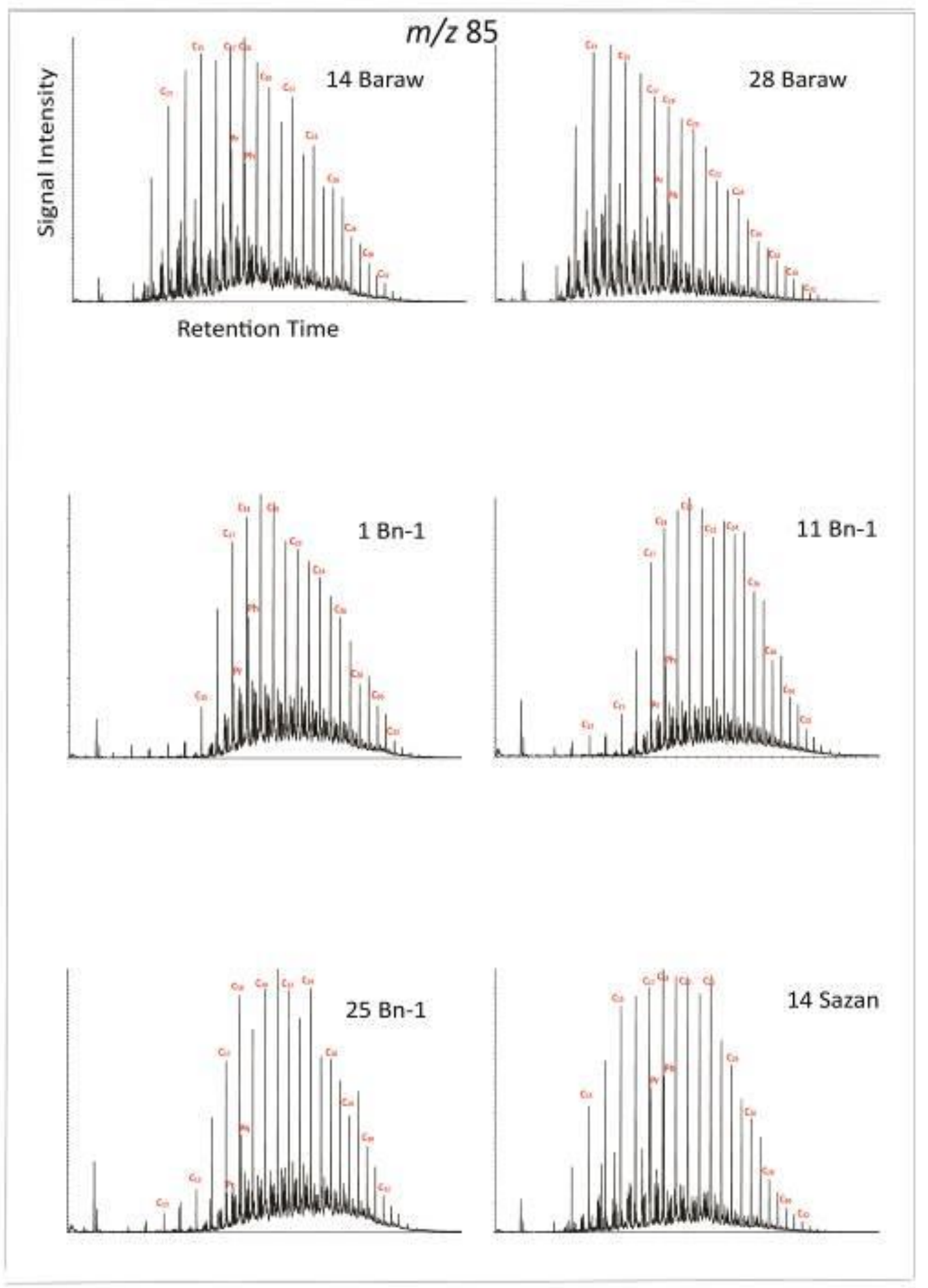

Figure 8- Mass chromatograms $(m / z, 85)$ of saturated hydrocarbon fractions showing the $n$ - alkanes and isoprenoids distribution. 

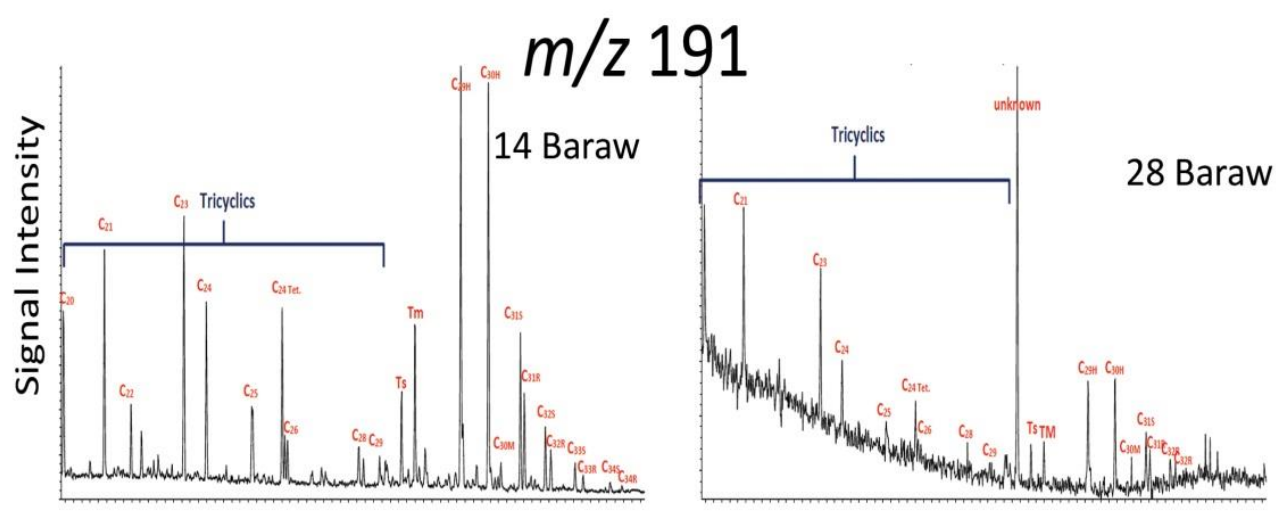

Retention Time
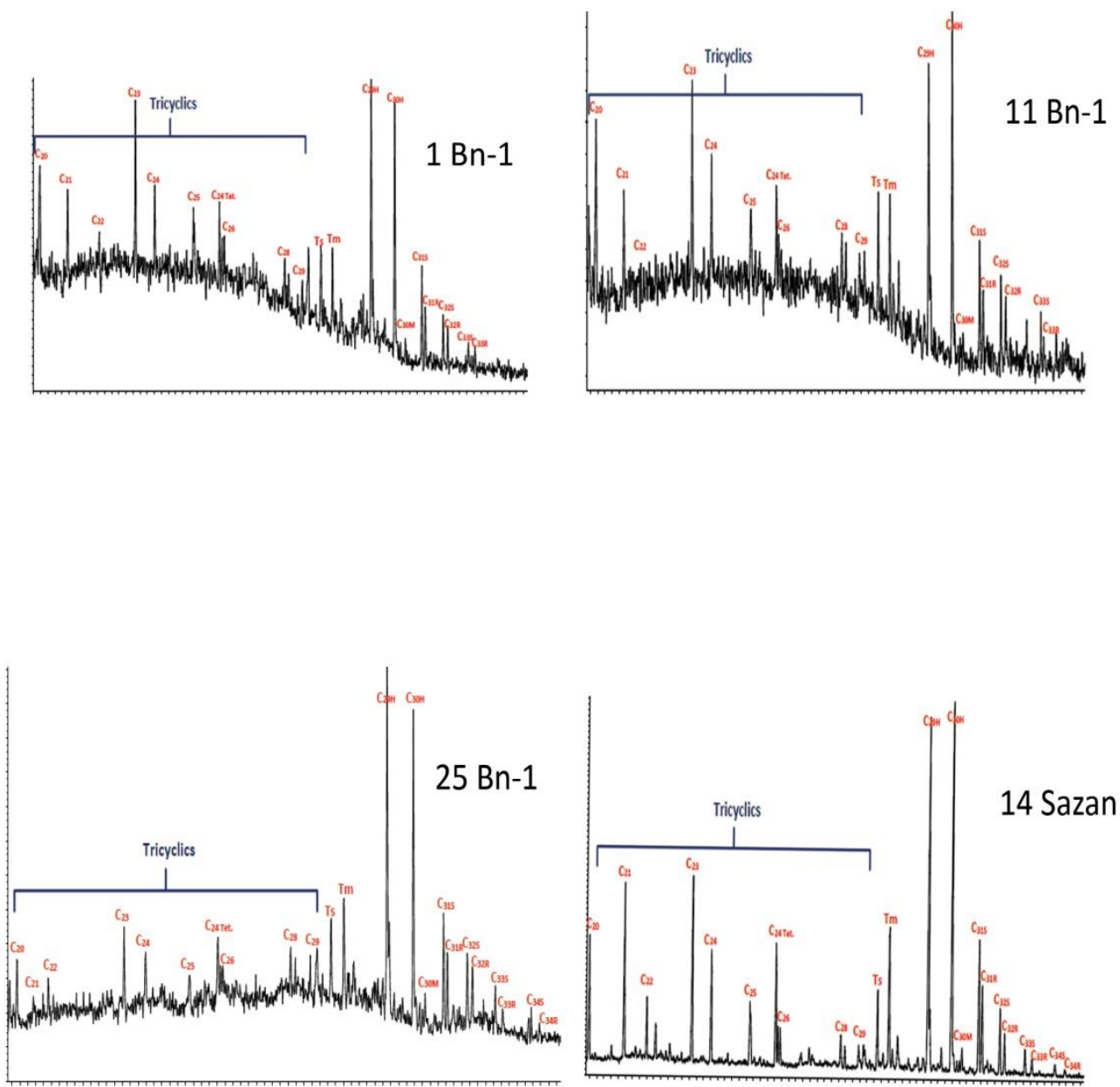

Figure 9- Mass chromatograms $(\mathrm{m} / \mathrm{z}$ 191) of saturated hydrocarbon fractions showing the distribution of hopanes (detailed compound abbreviations are shown in the appendix). 


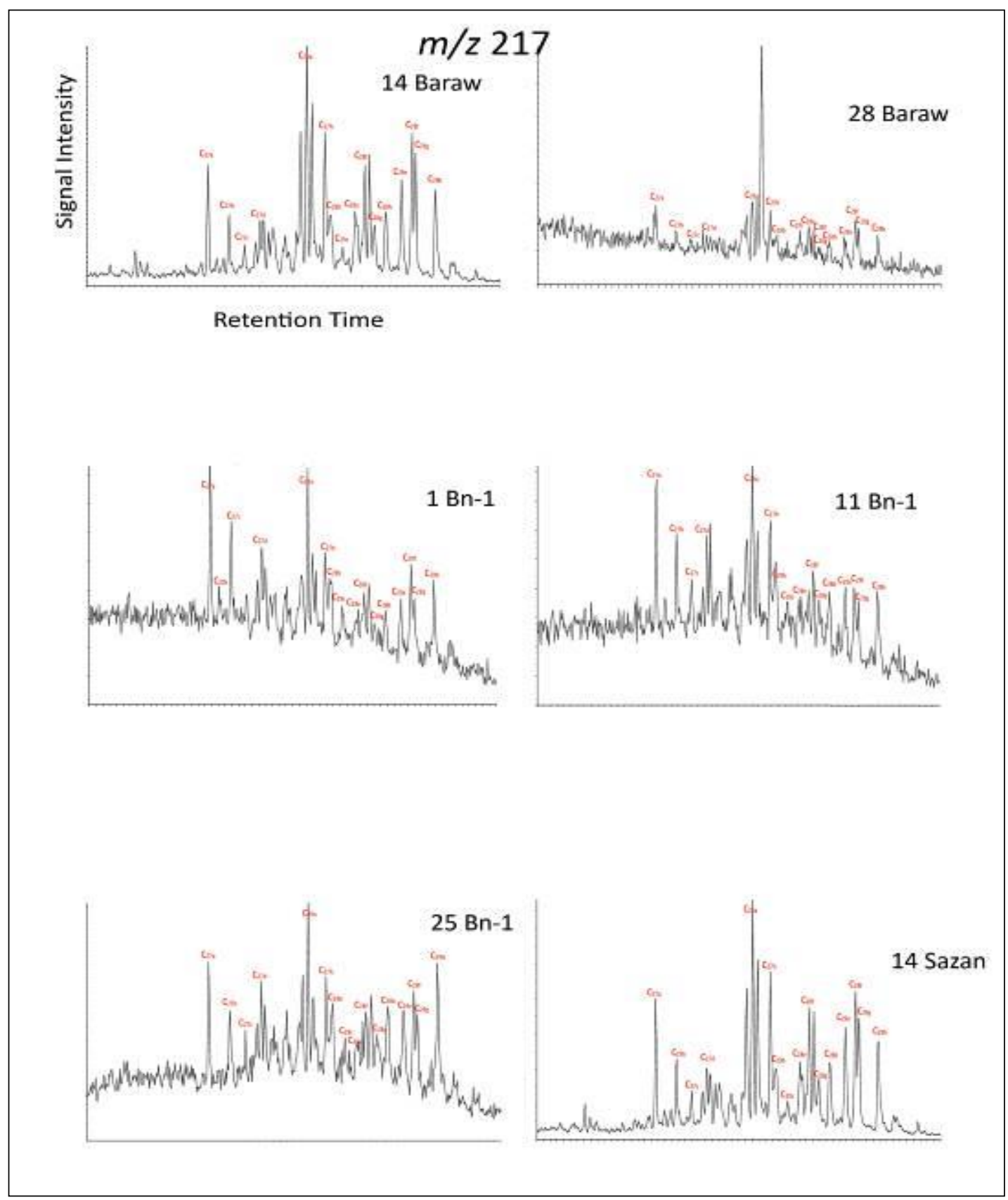

Figure 10- Mass chromatograms $(\mathrm{m} / \mathrm{z} 217)$ of saturated hydrocarbon fractions showing the distribution of steranes.

\section{Discussion}

\subsection{Origin of organic matter and paleodepositional environment}

The $n$-alkane distributions and their envelopes are unimodal, with short-chain compounds in the range of $n-\mathrm{C}_{14}$ to $n-\mathrm{C}_{22}$ being predominant (Figure-8). However, some differences are noticed for samples of Baraw, which are richer in light hydrocarbons as compared to the other sections. This type of distribution usually indicates marine plankton [24]. Heavy $n$-alkanes in the range of $\mathrm{C}_{30}$ to $\mathrm{C}_{40}$ are very low, which is pointing to the contribution of higher plant waxes [38]. The amount of $\mathrm{C}_{26}$ to $\mathrm{C}_{32} n$ alkanes in $\mathrm{Bn}-1$ section is higher than that in the other sections, indicating some input of higher plants to the organic matters of Balambo Formation (Figure- 8). The same conclusions are obtained with the TAR ratio, in which the Baraw and Sazan samples have low value (0.15-0.25), indicating dominance of aquatic organic matter. While the Bn-1 samples have moderate to high $(0.45-1.07)$ ratio, which indicates moderate terrigenous organic matter input (Table- 2). Additionally, the ternary diagrams of $\mathrm{C}_{27}, \mathrm{C}_{28}$, and $\mathrm{C}_{29}$ steranes in the Baraw and Sazan samples show planktonic-bacterial origin, while 
those of the Bn-1samples are of both planktonic bacterial and planktonic-land plants origins (Figure-12).

Values lower than 0.85 for $\mathrm{C} 27 / \mathrm{C} 29$ sterane ratios are believed to be indicative of terrestrial organic matter, whilst values between 0.85 and 1.43 indicate mixed organic material, and values higher than 1.43 suggest an input of predominantly marine organic matter [29, 39, 40]. The results of the $\mathrm{C}_{27} / \mathrm{C}_{29}$ ratio of the analyzed samples show that sample no. 25 of $\mathrm{Bn}-1$ section has a value of 0.8 , which indicates terrestrial organic matter, while the Bn-1 samples and sample no. 28 of Baraw section have a range from 1.02 to 1.36 , indicating mixed algal and land plants origin with deposition under anoxic condition. Sample no. 14 of Baraw section and Sazan sample have values of 1.50 and 1.55 (> 1.43), respectively, indicating an input of marine organic matter (Figure- 13). The same conclusion is obtained from the ratios of $\mathrm{C}_{31}-22 \mathrm{R}$-hopane/ $\mathrm{C}_{30}$-hopane, which is used to distinguish between different depositional environments, with a value higher than 0.25 indicating a marine environment [21]. The analyzed samples have a range between 0.23 and 0.41 (Table- 2), with most of them having values of $>0.25$, indicating a marine environment. Exceptions include samples number 5, 11, and 25 of the Bn1 section that show values lower than 0.25 , which is possibly caused by some terrestrial input.

The cross plot of $\mathrm{Pr} / n-\mathrm{C}_{17}$ versus $\mathrm{Ph} / n-\mathrm{C}_{18}$ indicates that the Baraw and Sazan samples are located at the border between algal marine and mixed OM transitional environment. They have kerogen type II/III and algal marine organic matter of type II kerogen, while all Bn-1 samples are of algal marine organic matter of type II kerogen field (Figure- 11). It has been suggested that marine phytoplankton is characterized by the dominance of $\mathrm{C}_{27}$ steranes, whereas the preponderance of $\mathrm{C}_{29}$ compounds indicates strong terrestrial contributions [39].

The absence of Gammacerane is an indicator of normal marine water depositional environment of Balambo Formation. The absence of Oleanane indicates that the sediments were deposited far from the input of the angiosperm higher plant, since their deposition occurred prior to the evolution of angiosperms [41, 42]. The $\mathrm{m} / \mathrm{z} 191$ chromatograms of Balambo Formation show no Oleanane compounds (Figure- 9), because Oleanane has been reported in Upper Cretaceous and Tertiary source rocks [42]. In addition, some of the samples show a terrestrial input, where Oleanane was also not detected.

The $\mathrm{C}_{29}$ norhopane $/ \mathrm{C}_{30}$ hopane ratio is used to distinguish the carbonate $(>1.0)$ and clastic lithology (clay rich, shale source rock <1.0). In this study, this ratio ranges from 0.81 to 1.13 (Table- 2), indicating the mixed carbonate and shale facies of the Balambo Formation. Similar conclusion is obtained from the ratio of $\mathrm{C}_{22} / \mathrm{C}_{21}$ versus $\mathrm{C}_{24} / \mathrm{C}_{23}$ tricyclic terpane (Figure-14). These results are concordant with the lithology of Balambo Formation, which is mostly composed of limestone and less shale layers.

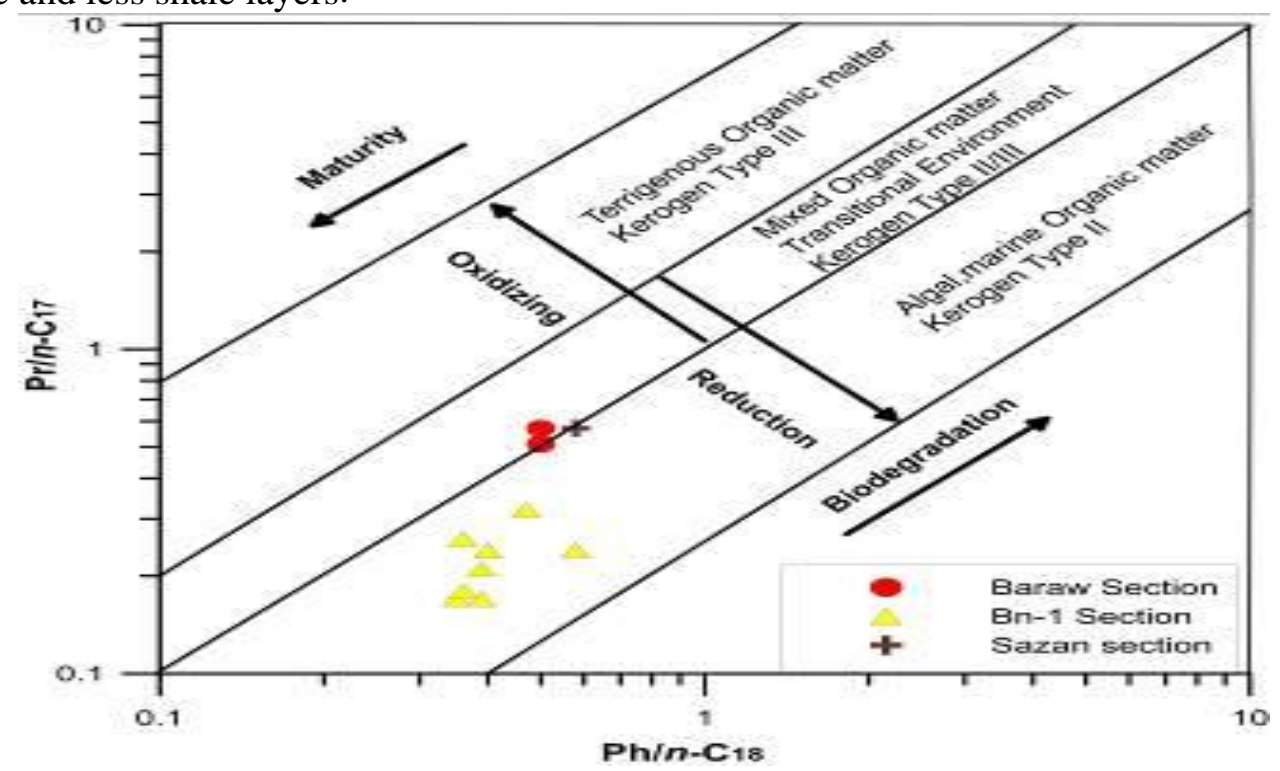

Figure 11- Cross plot of Pristane $/ n-\mathrm{C}_{17}$ versus Phytane $/ n-\mathrm{C}_{18}$ (32) showing that the Baraw and section samples are located in the marine and transitional environment, while Bn-1 samples are located in the marine environment. 


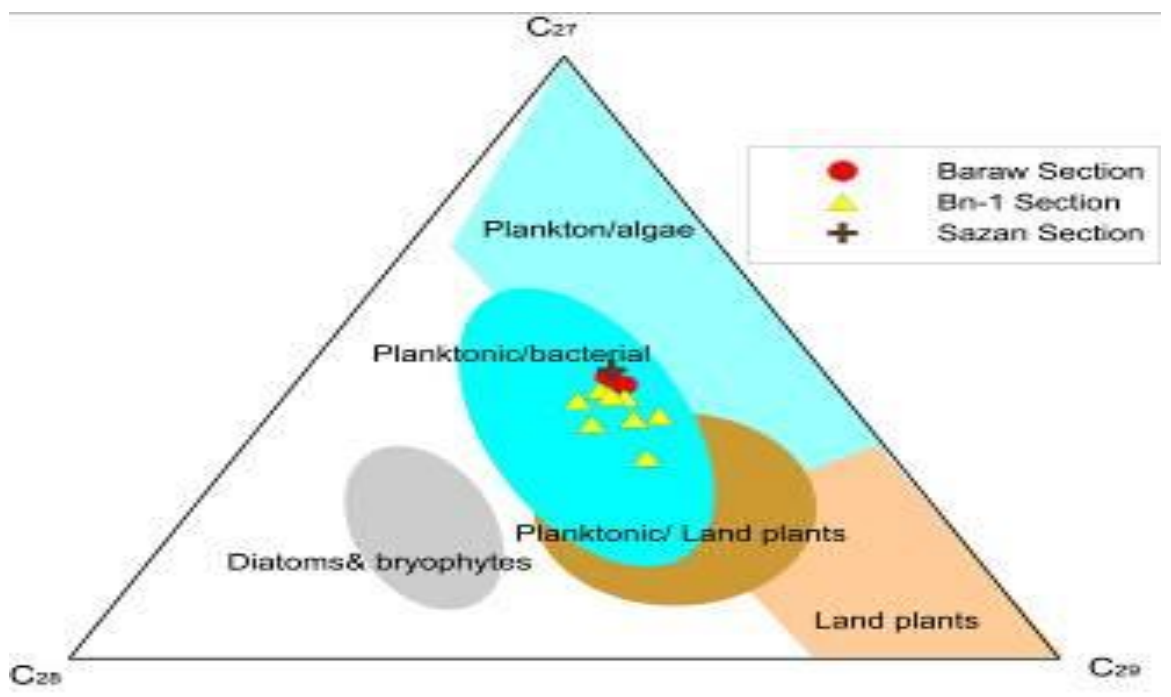

Figure 12-Ternary diagram of regular steranes $\left(\mathrm{C}_{27}-\mathrm{C}_{28}-\mathrm{C}_{29}\right)$ indicating the relationship between sterane compositions in relation to organic matter input.

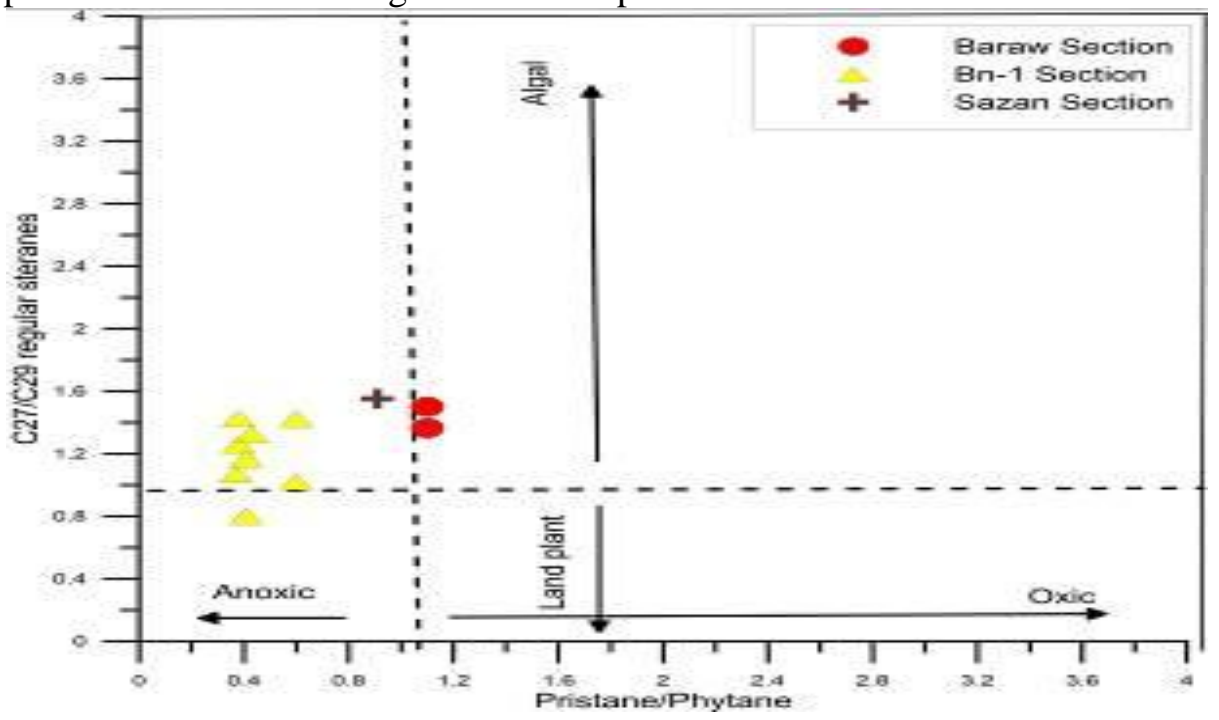

Figure 13- Cross plot of $\mathrm{C} 27 / \mathrm{C} 29$ steranes and Pristane/Phytane ratio for the study samples from Balambo Formation, Northeastern Iraq.



Figure 14- Plot of $\mathrm{C}_{22} / \mathrm{C}_{21}$ Tricyclic terpane and $\mathrm{C}_{24} / \mathrm{C}_{23}$ tricyclic terpane, with location of samples [21]. 
Table 2- Bulk organic geochemical biomarker parameters and ratios of $n$ - alkanes, isoprenoides hopanes, tricyclic, tetracyclic terpanes and steranes of the analyzed samples form Baraw, Bn-1 and Sazan sections, Northeast Iraq, Kurdistan Region

\begin{tabular}{|c|c|c|c|c|c|c|c|c|c|c|c|c|c|c|c|c|c|c|c|c|c|c|}
\hline \multirow[b]{3}{*}{ 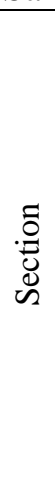 } & \multirow{3}{*}{  } & \multirow{2}{*}{\multicolumn{5}{|c|}{$\begin{array}{c}n \text {-alkane and } \\
\text { isoprenoids }\end{array}$}} & \multicolumn{10}{|c|}{ Triterpanes and terpanes $(\mathrm{m} / \mathrm{z}$ 191) } & \multicolumn{6}{|c|}{ Steranes $(\mathbf{m} / \mathbf{z} 217)$} \\
\hline & & & & & & & \multicolumn{6}{|c|}{ Hopanes } & \multicolumn{7}{|c|}{$\begin{array}{l}\text { Tricyclic (Tri) and tetracyclic } \\
\text { (Tetra) terpanes }\end{array}$} & \multicolumn{3}{|c|}{$\begin{array}{c}\text { Regular } \\
\text { steranes }(\%)\end{array}$} \\
\hline & & 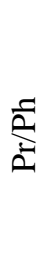 & $\bar{\Xi}$ & $\frac{\infty}{U}$ & $\overline{0}$ & 宸 & 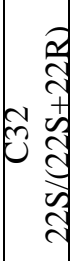 &  & $\stackrel{\Xi}{E}$ & 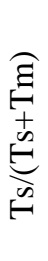 & 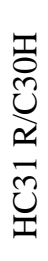 & 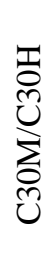 & 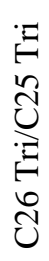 & $\begin{array}{l}\bar{\mho} \\
\text { ป̂ }\end{array}$ & 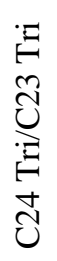 & 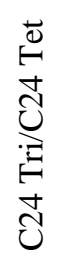 & 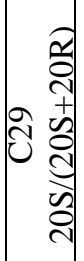 & 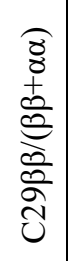 &  & $\begin{array}{c}\mathrm{C} \\
27\end{array}$ & $\begin{array}{l}\mathrm{C} \\
28\end{array}$ & $\begin{array}{l}\mathrm{C} \\
29\end{array}$ \\
\hline $\begin{array}{l}\text { Bar } \\
\text { aw }\end{array}$ & $\begin{array}{l}1 \\
4\end{array}$ & $\begin{array}{l}1 . \\
1\end{array}$ & $\begin{array}{l}0 . \\
57\end{array}$ & $\begin{array}{c}0 . \\
5\end{array}$ & $\begin{array}{l}0 . \\
93\end{array}$ & $\begin{array}{l}0 . \\
25\end{array}$ & $\begin{array}{l}0 . \\
6\end{array}$ & $\begin{array}{l}1 . \\
04\end{array}$ & $\begin{array}{l}0 . \\
58\end{array}$ & $\begin{array}{l}0 . \\
36\end{array}$ & $\begin{array}{l}0 . \\
25\end{array}$ & $\begin{array}{l}0 . \\
11\end{array}$ & $\begin{array}{l}0 . \\
66\end{array}$ & $\begin{array}{l}0 . \\
38\end{array}$ & $\begin{array}{c}0 . \\
7\end{array}$ & $\begin{array}{l}1 . \\
09\end{array}$ & $\begin{array}{l}0 . \\
53\end{array}$ & $\begin{array}{l}0 . \\
56\end{array}$ & $\begin{array}{l}1 . \\
5\end{array}$ & $\begin{array}{c}46 . \\
67\end{array}$ & $\begin{array}{l}22 . \\
22\end{array}$ & $\begin{array}{l}31 \\
11\end{array}$ \\
\hline $\begin{array}{l}\text { Bar } \\
\text { aw }\end{array}$ & $\begin{array}{l}2 \\
8\end{array}$ & $\begin{array}{c}1 . \\
1\end{array}$ & $\begin{array}{l}0 . \\
51\end{array}$ & $\begin{array}{c}0 . \\
5\end{array}$ & $\begin{array}{l}1 . \\
03\end{array}$ & $\begin{array}{l}0 . \\
15\end{array}$ & $\begin{array}{c}0 . \\
6\end{array}$ & 1 & 1 & $\begin{array}{l}0 . \\
57\end{array}$ & $\begin{array}{l}0 . \\
41\end{array}$ & $\begin{array}{l}0 . \\
22\end{array}$ & $\begin{array}{l}0 . \\
75\end{array}$ & $\begin{array}{l}0 . \\
47\end{array}$ & $\begin{array}{l}0 . \\
52\end{array}$ & $\begin{array}{l}1 . \\
08\end{array}$ & $\begin{array}{l}0 . \\
48\end{array}$ & $\begin{array}{l}0 . \\
55\end{array}$ & $\begin{array}{l}1 . \\
36\end{array}$ & $\begin{array}{l}45 . \\
45\end{array}$ & $\begin{array}{l}21 . \\
21\end{array}$ & $\begin{array}{l}33 \\
33\end{array}$ \\
\hline $\begin{array}{c}\mathrm{Bn}- \\
1\end{array}$ & 1 & $\begin{array}{l}0 . \\
6\end{array}$ & $\begin{array}{l}0 . \\
32\end{array}$ & $\begin{array}{l}0 . \\
47\end{array}$ & $\begin{array}{l}1 . \\
06\end{array}$ & $\begin{array}{l}0 . \\
45\end{array}$ & $\begin{array}{l}0 . \\
6\end{array}$ & $\begin{array}{l}1 . \\
05\end{array}$ & 1 & $\begin{array}{l}0 . \\
5\end{array}$ & $\begin{array}{l}0 . \\
25\end{array}$ & $\begin{array}{l}0 . \\
13\end{array}$ & $\begin{array}{l}0 . \\
85\end{array}$ & $\begin{array}{l}0 . \\
77\end{array}$ & $\begin{array}{c}0 . \\
5\end{array}$ & $\begin{array}{l}1 . \\
05\end{array}$ & $\begin{array}{l}0 . \\
43\end{array}$ & $\begin{array}{l}0 . \\
53\end{array}$ & $\begin{array}{l}1 . \\
02\end{array}$ & $\begin{array}{c}40 . \\
06\end{array}$ & $\begin{array}{l}20 . \\
31\end{array}$ & $\begin{array}{l}39 \\
63\end{array}$ \\
\hline $\begin{array}{c}\mathrm{Bn}- \\
1\end{array}$ & 5 & $\begin{array}{c}0 . \\
38\end{array}$ & $\begin{array}{l}0 . \\
17\end{array}$ & $\begin{array}{l}0 . \\
39\end{array}$ & $\begin{array}{l}1 . \\
17\end{array}$ & $\begin{array}{l}0 . \\
63\end{array}$ & $\begin{array}{l}0 . \\
7\end{array}$ & $\begin{array}{l}0 . \\
83\end{array}$ & $\begin{array}{l}1 . \\
13\end{array}$ & $\begin{array}{l}0 . \\
53\end{array}$ & $\begin{array}{l}0 . \\
23\end{array}$ & $\begin{array}{l}0 . \\
12\end{array}$ & $\begin{array}{l}1 . \\
04\end{array}$ & $\begin{array}{l}1 . \\
07\end{array}$ & $\begin{array}{l}0 . \\
61\end{array}$ & $\begin{array}{l}1 . \\
21\end{array}$ & $\begin{array}{l}0 . \\
41\end{array}$ & $\begin{array}{l}0 . \\
53\end{array}$ & $\begin{array}{l}1 . \\
42\end{array}$ & $\begin{array}{l}42 . \\
73\end{array}$ & $\begin{array}{l}27 . \\
27\end{array}$ & 30 \\
\hline $\begin{array}{c}\mathrm{Bn}- \\
1\end{array}$ & 7 & $\begin{array}{c}0 . \\
38\end{array}$ & $\begin{array}{l}0 . \\
17\end{array}$ & $\begin{array}{c}0 . \\
35\end{array}$ & $\begin{array}{l}1 . \\
1\end{array}$ & $\begin{array}{l}0 . \\
69\end{array}$ & $\begin{array}{c}0 . \\
6\end{array}$ & $\begin{array}{c}0 . \\
97\end{array}$ & $\begin{array}{c}0 . \\
85\end{array}$ & $\begin{array}{l}0 . \\
46\end{array}$ & $\begin{array}{c}0 . \\
32\end{array}$ & $\begin{array}{l}0 . \\
12\end{array}$ & 1 & $\begin{array}{l}0 . \\
67\end{array}$ & $\begin{array}{c}0 . \\
55\end{array}$ & $\begin{array}{l}0 . \\
92\end{array}$ & $\begin{array}{l}0 . \\
43\end{array}$ & $\begin{array}{c}0 . \\
6\end{array}$ & $\begin{array}{l}1 . \\
26\end{array}$ & $\begin{array}{c}43 . \\
33\end{array}$ & $\begin{array}{l}22 . \\
22\end{array}$ & $\begin{array}{l}34 . \\
44\end{array}$ \\
\hline $\begin{array}{c}\text { Bn- } \\
1\end{array}$ & $\begin{array}{l}1 \\
1\end{array}$ & $\begin{array}{c}0 . \\
6\end{array}$ & $\begin{array}{l}0 . \\
26\end{array}$ & $\begin{array}{l}0 . \\
36\end{array}$ & $\begin{array}{c}1 . \\
05\end{array}$ & $\begin{array}{c}0 . \\
5\end{array}$ & $\begin{array}{r}0 . \\
6\end{array}$ & $\begin{array}{c}0 . \\
81\end{array}$ & 1 & $\begin{array}{c}0 . \\
5\end{array}$ & $\begin{array}{l}0 . \\
24\end{array}$ & $\begin{array}{l}0 . \\
12\end{array}$ & $\begin{array}{c}0 . \\
86\end{array}$ & $\begin{array}{l}0 . \\
63\end{array}$ & $\begin{array}{l}0 . \\
67\end{array}$ & $\begin{array}{l}1 . \\
5\end{array}$ & $\begin{array}{l}0 . \\
46\end{array}$ & $\begin{array}{l}0 . \\
57\end{array}$ & $\begin{array}{l}1 . \\
42\end{array}$ & $\begin{array}{c}44 . \\
58\end{array}$ & $\begin{array}{c}24 . \\
1\end{array}$ & $\begin{array}{l}31 . \\
33\end{array}$ \\
\hline $\begin{array}{c}\text { Bn- } \\
1\end{array}$ & $\begin{array}{l}1 \\
5\end{array}$ & $\begin{array}{l}0 . \\
43\end{array}$ & $\begin{array}{l}0 . \\
18\end{array}$ & $\begin{array}{l}0 . \\
36\end{array}$ & $\begin{array}{l}1 . \\
16\end{array}$ & $\begin{array}{l}0 . \\
88\end{array}$ & $\begin{array}{c}0 . \\
6\end{array}$ & $\begin{array}{l}1 . \\
11\end{array}$ & $\begin{array}{c}0 . \\
89\end{array}$ & $\begin{array}{l}0 . \\
47\end{array}$ & $\begin{array}{l}0 . \\
33\end{array}$ & $\begin{array}{c}0 . \\
13\end{array}$ & $\begin{array}{c}0 . \\
94\end{array}$ & $\begin{array}{l}1 . \\
36\end{array}$ & $\begin{array}{l}0 . \\
81\end{array}$ & $\begin{array}{c}1 . \\
55\end{array}$ & $\begin{array}{l}0 . \\
46\end{array}$ & $\begin{array}{l}0 . \\
57\end{array}$ & $\begin{array}{l}1 . \\
32\end{array}$ & $\begin{array}{c}43 . \\
53\end{array}$ & $\begin{array}{l}23 . \\
53\end{array}$ & $\begin{array}{l}32 . \\
94\end{array}$ \\
\hline $\begin{array}{c}\text { Bn- } \\
1\end{array}$ & $\begin{array}{l}2 \\
1\end{array}$ & $\begin{array}{c}0 . \\
41\end{array}$ & $\begin{array}{l}0 . \\
24\end{array}$ & $\begin{array}{l}0 . \\
4\end{array}$ & $\begin{array}{l}1 . \\
1\end{array}$ & $\begin{array}{l}0 . \\
64\end{array}$ & $\begin{array}{l}0 . \\
6\end{array}$ & $\begin{array}{c}0 . \\
96\end{array}$ & $\begin{array}{l}1 . \\
1\end{array}$ & $\begin{array}{l}0 . \\
52\end{array}$ & $\begin{array}{c}0 . \\
26\end{array}$ & $\begin{array}{l}0 . \\
07\end{array}$ & $\begin{array}{c}0 . \\
93\end{array}$ & $\begin{array}{c}0 . \\
89\end{array}$ & $\begin{array}{c}0 . \\
5\end{array}$ & $\begin{array}{c}1 . \\
12\end{array}$ & $\begin{array}{l}0 . \\
47\end{array}$ & $\begin{array}{c}0 . \\
63\end{array}$ & $\begin{array}{l}1 . \\
17\end{array}$ & $\begin{array}{l}38 . \\
89\end{array}$ & $\begin{array}{l}27 . \\
78\end{array}$ & $\begin{array}{l}33 \\
33\end{array}$ \\
\hline $\begin{array}{c}\mathrm{Bn}- \\
1\end{array}$ & $\begin{array}{l}2 \\
5\end{array}$ & $\begin{array}{c}0 . \\
41\end{array}$ & 0. & 0. & $\begin{array}{c}0 . \\
93\end{array}$ & $\begin{array}{l}0 . \\
86\end{array}$ & $\begin{array}{c}0 . \\
6\end{array}$ & $\begin{array}{l}1 . \\
13\end{array}$ & $\begin{array}{c}0 . \\
84\end{array}$ & $\begin{array}{l}0 . \\
47\end{array}$ & $\begin{array}{l}0 . \\
24\end{array}$ & $\begin{array}{c}0 . \\
1\end{array}$ & $\begin{array}{l}1 . \\
11\end{array}$ & $\begin{array}{l}1 . \\
17\end{array}$ & $\begin{array}{l}0 . \\
68\end{array}$ & $\begin{array}{c}0 . \\
93\end{array}$ & $\begin{array}{l}0 . \\
4\end{array}$ & $\begin{array}{c}0 . \\
6\end{array}$ & $\begin{array}{c}0 . \\
8\end{array}$ & $\begin{array}{l}33 . \\
33\end{array}$ & 25 & $\begin{array}{l}41 . \\
67\end{array}$ \\
\hline $\begin{array}{c}\text { Bn- } \\
1\end{array}$ & $\begin{array}{l}2 \\
9\end{array}$ & $\begin{array}{c}0 . \\
37\end{array}$ & $\begin{array}{l}0 . \\
24\end{array}$ & $\begin{array}{c}0 . \\
58\end{array}$ & $\begin{array}{c}1 . \\
14\end{array}$ & $\begin{array}{c}1 . \\
07\end{array}$ & $\begin{array}{l}0 . \\
7\end{array}$ & $\begin{array}{c}1 . \\
03\end{array}$ & $\begin{array}{l}0 . \\
96\end{array}$ & $\begin{array}{l}0 . \\
49\end{array}$ & $\begin{array}{c}0 . \\
27\end{array}$ & $\begin{array}{c}0 . \\
08\end{array}$ & $\begin{array}{c}0 . \\
94\end{array}$ & $\begin{array}{l}0 . \\
83\end{array}$ & $\begin{array}{l}0 . \\
81\end{array}$ & $\begin{array}{c}0 . \\
87\end{array}$ & $\begin{array}{l}0 . \\
45\end{array}$ & $\begin{array}{c}0 . \\
56\end{array}$ & $\begin{array}{c}1 . \\
07\end{array}$ & $\begin{array}{l}39 . \\
74\end{array}$ & $\begin{array}{l}23 . \\
08\end{array}$ & $\begin{array}{l}37 . \\
18\end{array}$ \\
\hline $\begin{array}{c}\text { Saz } \\
\text { an }\end{array}$ & $\begin{array}{l}1 \\
4\end{array}$ & $\begin{array}{c}0 . \\
91\end{array}$ & $\begin{array}{l}0 . \\
57\end{array}$ & $\begin{array}{c}0 . \\
58\end{array}$ & $\begin{array}{l}0 . \\
97\end{array}$ & $\begin{array}{l}0 . \\
2\end{array}$ & $\begin{array}{l}0 . \\
6\end{array}$ & $\begin{array}{l}0 . \\
95\end{array}$ & $\begin{array}{l}0 . \\
61\end{array}$ & $\begin{array}{l}0 . \\
38\end{array}$ & $\begin{array}{l}0 . \\
26\end{array}$ & $\begin{array}{c}0 . \\
1\end{array}$ & $\begin{array}{l}0 . \\
65\end{array}$ & $\begin{array}{l}0 . \\
39\end{array}$ & $\begin{array}{l}0 . \\
62\end{array}$ & $\begin{array}{l}0 . \\
92\end{array}$ & $\begin{array}{l}0 . \\
52\end{array}$ & $\begin{array}{c}0 . \\
56\end{array}$ & $\begin{array}{c}1 . \\
55\end{array}$ & $\begin{array}{l}47 . \\
87\end{array}$ & $\begin{array}{l}21 . \\
28\end{array}$ & $\begin{array}{l}30 . \\
85\end{array}$ \\
\hline
\end{tabular}

Pr: Pristane; Ph: Phytane; CPI - Carbon preference index $=\left(2\left(\mathrm{C}_{23}+\mathrm{C}_{25}+\mathrm{C}_{27}+\mathrm{C}_{29}\right) /\left[\mathrm{C}_{22}+2\right.\right.$ $\left.\left(\mathrm{C}_{24}+\mathrm{C}_{26}+\mathrm{C}_{28)}+\mathrm{C}_{30}\right]\right)$.

Ts: $\left(\mathrm{C}_{27} 18 \alpha(\mathrm{H})-22,29\right.$, 30-trisnorneohopane); Tm: $\left(\mathrm{C}_{27} 17 \alpha(\mathrm{H})-22,29\right.$, 30-trisnorhopane); $\mathrm{HCR}_{31} / \mathrm{C}_{30} \mathrm{H}: \mathrm{C}_{31}$ regular homohopane/ $\mathrm{C}_{30}$ hopane; $\mathrm{C}_{29} \mathrm{H} / \mathrm{C}_{30} \mathrm{H}: \mathrm{C}_{29}$ norhopane/ $\mathrm{C}_{30}$ hopane; $\mathrm{C}_{30} \mathrm{M} / \mathrm{C}_{30} \mathrm{H}: \mathrm{C}_{30}$ moretane/ $\mathrm{C}_{30}$ hopane; TAR: Terrigenous Aqueous Ratio (Terrigenous/ aquatic) ratio= $\left(\mathrm{C}_{27}+\mathrm{C}_{29}+\mathrm{C}_{31}\right) /\left(\mathrm{C}_{15}+\mathrm{C}_{17}+\mathrm{C}_{19)}\right.$.

\subsection{Thermal Maturity Assessment}

Several parameters were used in this study to evaluate the level of organic matter maturity. These include CPI, Ts/Tm, $\mathrm{C}_{32}$ hopane $22 \mathrm{~S} /(22 \mathrm{~S}+22 \mathrm{R}), \mathrm{C} 29 \beta \beta /(\beta \beta+\alpha \alpha)$, and $\mathrm{C}_{29^{-}}$sterane $20 \mathrm{~S} /(20 \mathrm{~S}+20 \mathrm{R})$ ratios.

The CPI values of the seven samples of Bn-1 and one sample of Baraw indicate maturation, while the other samples show a predominance of marine input and /or thermal maturation. The ratios of $\mathrm{C}_{29}$ $20 \mathrm{~S} /(20 \mathrm{~S}+20 \mathrm{R})$ and $\beta \beta /(\beta \beta+\alpha \alpha)$ steranes increase with increasing maturity [4, 44]. The relationship between $\mathrm{C}_{29} \beta \beta /(\beta \beta+\alpha \alpha)$ and $\mathrm{C}_{29} 20 \mathrm{~S} /(20 \mathrm{~S}+20 \mathrm{R})$ steranes of the studied samples indicate a peak mature zone (Table -2; Figure- 15).

$\mathrm{C}_{32} 22 \mathrm{~S} / 22 \mathrm{~S}+22 \mathrm{R}$ homohopane ratio increases from zero to about 0.6 at equilibrium during maturation [45]. Values in the range of 0.50 to 0.54 have barely entered oil generation, whereas ratios from 0.57 up to 0.62 indicate an oil window zone [21]. All the analyzed samples have a range from 0.57 to 0.66 , which suggests that they have entered oil generation and that the oil window has been reached (Figure-16).

The ratio of $\mathrm{C}_{30} \mathrm{M} / \mathrm{C}_{30} \mathrm{H}$ decreases with increasing maturity from 0.15 immature bitumens to a minimum of 0.05 mature source rock and oils [46]. The analyzed samples show that this ratio ranges from 0.07 to 0.22 , indicating their early mature to mature character (Table- 2 ). 
The ratio of $\mathrm{Ts} /(\mathrm{Ts}+\mathrm{Tm})$ or $\mathrm{Ts} / \mathrm{Tm}$ is another indicator of the rock maturity [30,47]. It increases with maturity but may also be influenced by source lithology. Carbonate rocks appear to have a low Ts/ $(\mathrm{Ts}+\mathrm{Tm})$ ratio as compared to shale [21, 47]. In this study, this ratio ranges between 0.36 and 0.57 (Table-2), which is an indication that the analyzed samples are mostly composed of mixed carbonate and shale facies, and are thermally mature source rock.

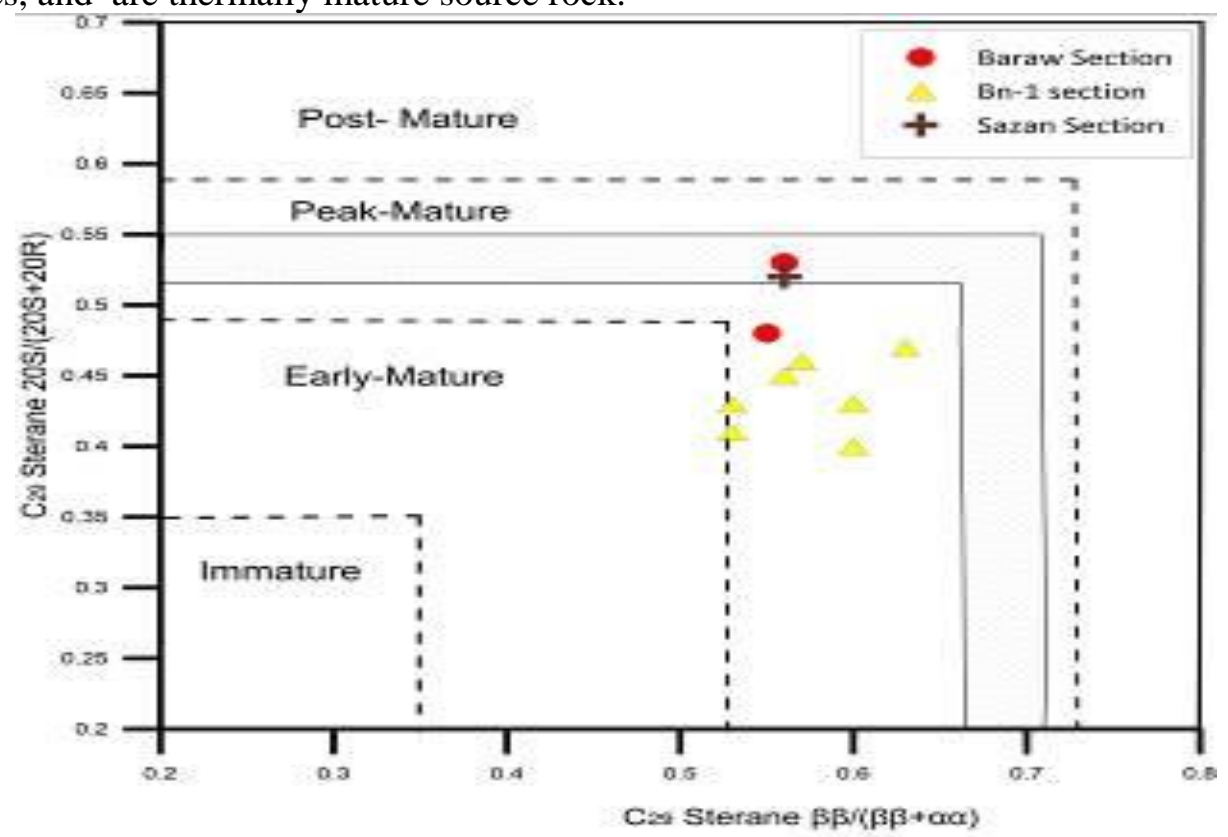

Figure 15- Cross plot of $\mathrm{C}_{29}$ sterane $\beta \beta /(\beta \beta+\alpha \alpha)$ and $\mathrm{C}_{29}$ sterane $20 \mathrm{~S} /(20 \mathrm{~S}+20 \mathrm{R})$ [21].

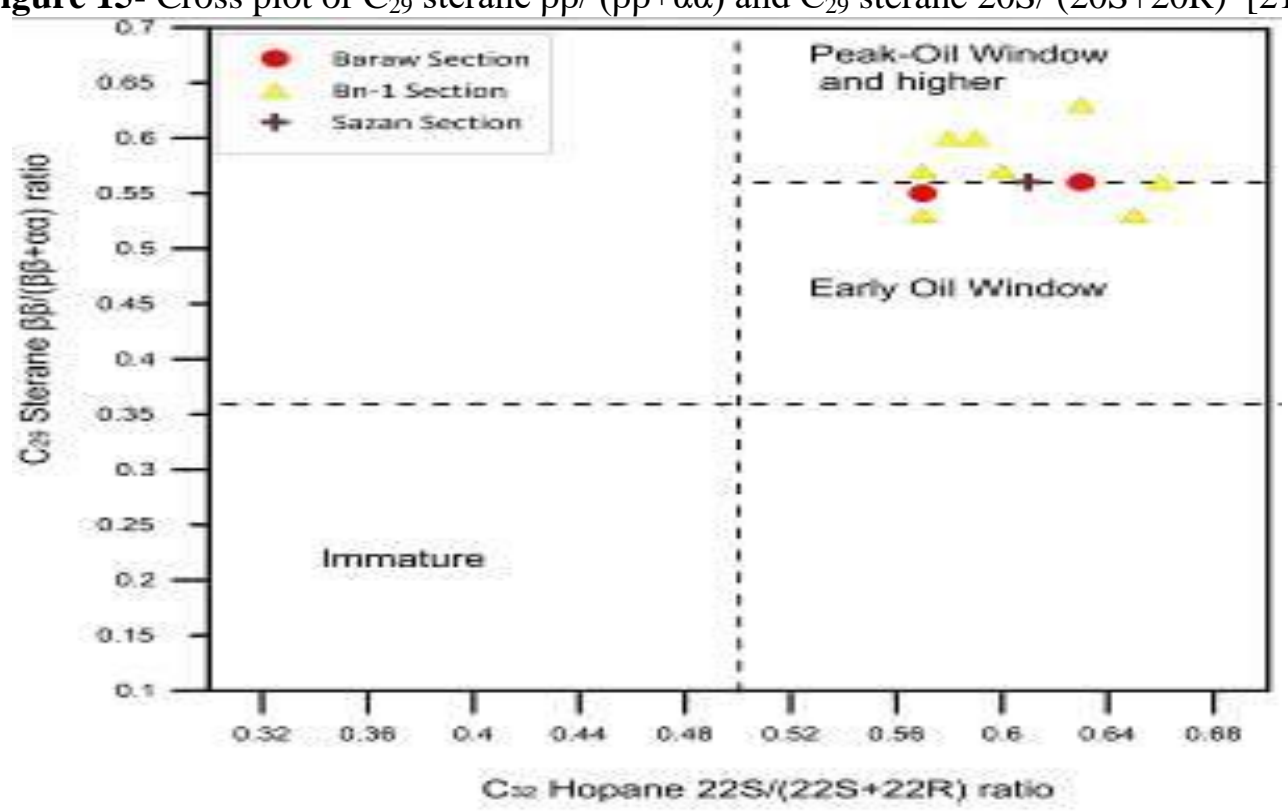

Figure 16- $\mathrm{C}_{32}$ hopane $22 \mathrm{~S} /(22 \mathrm{~S}+22 \mathrm{R})$ ratio and $\mathrm{C}_{29}$ sterane $\beta \beta /(\beta \beta+\alpha \alpha)$ ratio indicating early- peak oil window of the studied samples.

\section{Conclusions}

The evaluation of rock samples from Balambo Formation in three sections (Baraw, Bn-1, and Sazan) was geochemically accomplished through analyzing them by GC/MS to determine their kerogen types, hydrocarbon potentiality, depositional setting, and maturity of the source rock. The following key points can be drawn:

1- According to the EOM or bitumen content, both Bn-1 and Sazan samples are considered as organic rich sediments, while the Baraw samples are poor to fair source rocks. Based on TOC wt. $\%$ data, both Bn-1 and Sazan samples are considered as excellent source rocks. 
The Bn-1 samples are of kerogen type II (oil prone), whereas Sazan and Baraw samples are of type II/III (oil/ gas prone).

By plotting regular steranes in the ternary of $\mathrm{C}_{27}, \mathrm{C}_{28}$ and $\mathrm{C}_{29}$, the origin of the organic matter within rocks of Balambo Formation in $\mathrm{Bn}-1$ section is of both planktonic/ bacterial and planktonic/ land plants, whereas both Baraw and Sazan organic matters have the origin of planktonicbacterial.

Facies-indicating parameters, such as $\mathrm{C}_{22} / \mathrm{C}_{21}, \mathrm{C}_{24} / \mathrm{C}_{23}, \mathrm{C}_{31} \mathrm{R} / \mathrm{C}_{30} \mathrm{H}, \mathrm{C}_{26} / \mathrm{C}_{25}$, and $\mathrm{C}_{29} \mathrm{H} / \mathrm{C}_{30} \mathrm{H}$ show that the Balambo Formation is composed mostly of carbonate, with minor shale beds, which is consistent with the lithology of the formation.

Thermal maturity related biomarkers, such as $\mathrm{C} 29$ sterane $\alpha \alpha, \beta \beta, 20 \mathrm{~S}, \mathrm{C} 32$ hopane $22 \mathrm{~S}$, Ts/ $(\mathrm{Ts}+\mathrm{Tm})$, and $\mathrm{C}_{30} \mathrm{M} / \mathrm{C}_{30} \mathrm{H}$ show that all the investigated samples are mature and have entered the oil window (early-peak).

Depending on $\mathrm{Pr} / n-\mathrm{C}_{17}$ and $\mathrm{Ph} / n-\mathrm{C}_{18}$, the depositional environment of the Balambo Formation in $\mathrm{Bn}-1$ was found to be a marine and reduced environment, while in the Baraw and Sazan sections are of mixed marine and transitional environments.

\section{Acknowledgements}

This manuscript is a part of the first author's Ph.D. thesis. The authors take this opportunity to express their gratitude to the University of Sulaimani and Kurdistan Regional Government for funding this research under the Grant no. 7/2/13308. The authors are grateful to the Ministry of Natural Resources of Kurdistan, Kurdistan Regional Government, Iraq, for providing the samples of well Bn-1 and for their kind permission to publish this paper.

\section{Appendix}

Peak assignment for hydrocarbons in the gas chromatograms of saturated fractions in the $\mathrm{m} / z 191$ (I) and 217 (II) mass fragmentograms.

\begin{tabular}{|c|c|c|}
\hline (I) Peak no. & Compound abbreviation & \\
\hline $\mathrm{C} 20$ & C20 Tricyclic (Cheilanthane) & Tri C20 \\
\hline $\mathrm{C} 21$ & C21 Tricyclic (Cheilanthane) & Tri C21 \\
\hline $\mathrm{C} 22$ & C22 Tricyclic (Cheilanthane) & Tri C22 \\
\hline $\mathrm{C} 23$ & C23 Tricyclic (Cheilanthane) & Tri C23 \\
\hline $\mathrm{C} 24$ & C24 Tetracyclic & Tet $\mathrm{C} 24$ \\
\hline $\mathrm{C} 24$ & C24 Tricyclic (Cheilanthane) & Tri C24 \\
\hline $\mathrm{C} 25$ & C25 Tricyclic (Cheilanthane) & Tri C25 \\
\hline $\mathrm{C} 26$ & C26 Tricyclic (Cheilanthane) & Tri C26 \\
\hline $\mathrm{C} 27$ & C27 Tricyclic (Cheilanthane) & Tri C27 \\
\hline $\mathrm{C} 28$ & C28 Tricyclic (Cheilanthane) & Tri C28 \\
\hline $\mathrm{C} 29$ & C29 Tricyclic (Cheilanthane) & Tri C29 \\
\hline Ts & $18 \alpha(\mathrm{H}), 22,29,30$-trisnorneohopane & Ts \\
\hline $\mathrm{Tm}$ & $17 \alpha(\mathrm{H}), 22,29,30$-trisnorhopane & $\mathrm{Tm}$ \\
\hline $\mathrm{C} 29$ & $17 \alpha, 21 \beta(\mathrm{H})$-nor-hopane & C29 hop \\
\hline $\mathrm{C} 30 \mathrm{H}$ & $17 \alpha, 21 \beta(H)-$ hopane & Hopane \\
\hline $\mathrm{C} 30 \mathrm{M}$ & $17 \alpha, 21 \beta(\mathrm{H})$-Mortane & C30 Mortane \\
\hline $\mathrm{C} 31 \mathrm{~S}$ & $17 \alpha, 21 \beta(\mathrm{H})$ - homohopane $(22 \mathrm{~S})$ & C31 (22S) \\
\hline C31 R & $17 \alpha, 21 \beta(\mathrm{H})$ - homohopane (22R) & C31 (22R) \\
\hline $\mathrm{C} 32 \mathrm{~S}$ & $17 \alpha, 21 \beta(\mathrm{H})-$ homohopane $(22 \mathrm{~S})$ & C32 (22S) \\
\hline C32 R & $17 \alpha, 21 \beta(\mathrm{H})$ - homohopane (22R) & C32 (22R) \\
\hline C33 S & $17 \alpha, 21 \beta(\mathrm{H})-$ homohopane $(22 \mathrm{~S})$ & C33 (22S) \\
\hline $\mathrm{C} 33 \mathrm{R}$ & $17 \alpha, 21 \beta(\mathrm{H})$ - homohopane (22R) & $\mathrm{C} 33(22 \mathrm{R})$ \\
\hline $\mathrm{C} 34 \mathrm{~S}$ & $17 \alpha, 21 \beta(H)$ - homohopane (22S) & $\mathrm{C} 34(22 \mathrm{~S})$ \\
\hline $\mathrm{C} 34 \mathrm{R}$ & $17 \alpha, 21 \beta(\mathrm{H})$ - homohopane (22R) & $\mathrm{C} 34(22 \mathrm{R})$ \\
\hline
\end{tabular}

(II) Peak no.

a

b
$13 \beta, 17 \alpha(\mathrm{H})$ - diasteranes $20 \mathrm{~S}$

$13 \beta, 17 \alpha(\mathrm{H})$ - diasteranes $20 \mathrm{R}$
Diasteranes

Diasteranes 


$\begin{array}{lll}\mathrm{c} & 13 \beta, 17 \alpha(\mathrm{H}) \text { - diasteranes 20S } & \text { Diasteranes } \\ \mathrm{d} & 13 \beta, 17 \alpha(\mathrm{H}) \text { - diasteranes 20R } & \text { Diasteranes } \\ \mathrm{e} & 5 \alpha, 14 \alpha(\mathrm{H}), 17 \alpha(\mathrm{H}) \text {-steranes 20S } & \alpha \alpha \alpha 20 \mathrm{~S} \\ \mathrm{f} & 5 \alpha, 14 \beta(\mathrm{H}), 17 \beta(\mathrm{H}) \text {-steranes 20R } & \alpha \beta \beta 20 \mathrm{R} \\ \mathrm{g} & 5 \alpha, 14 \beta(\mathrm{H}), 17 \beta(\mathrm{H}) \text {-steranes 20S } & \alpha \beta \beta 20 \mathrm{~S} \\ \mathrm{~h} & 5 \alpha, 14 \alpha(\mathrm{H}), 17 \alpha(\mathrm{H}) \text {-steranes 20R } & \alpha \alpha \alpha 20 \mathrm{R}\end{array}$

\section{References}

1. Aqrawi, A. A., Goff, J. C., Horbury, A. D. and Sadooni, F. N. 2010. ThePetroleum Geology of Iraq. Scientific Press Ltd.1st edition, Beaconsfield, UK, 424 p.

2. Rashid, F., Hussein, D., Lawrence, J. and Khanaqa, P. 2020. Characterization and impact on reservoir quality of fractures in the Cretaceous Qamchuqa Formation, Zagros Folded Belt, Journal of Marine and Petroleum Geology (113):1-22.

3. Al- Ameri, T. K., Al- Khafaji, A.J., Zumberge, J. 2009. Petroleum system of The Mishrif reservoir, in the Ratawi, Zubair, North and south Rumaila oil fields, southern Iraq, GeoArabia, 14: $91-108$.

4. Al-Ameri, T. K. and Zumberge J. 2012. Middle and upper Jurassic hydrocarbons of The Zagros Fold Belt, North Iraq, Marine and Petroleum Geology, 36: 13-34.

5. Mahdi, A. Q. 2015. Najmah, Chia Gara and Balambo formations and related crude Oils, Northwestern Zagros Basin, Northern Iraq, M.Sc. Thesis,Mansoura University, Egypt.

6. Van Bellen, R. C., Dunnington H. V., Wetzel, R. and Morton, D. M., 1959 Lexique Stratigraphique International. Asie, Iraq, 333 p.

7. Buday, T. and Jassim S. Z., 1980. The Regional Geology of Iraq, Stratigraphy and Paleoecology. Volume 1, State Organization for Minerals, Baghdad, Iraq, 446 p.

8. Karim K. H., Al Khafaf, A. O. and Sharbazheri, K. M. I., 2016. Critical Analysis of the type section of Balambo Formation (Valanginian-Turonian), Sirwan Valley, Kurdistan Region, NEIraq. J. of Zankoy Sulaimani, Special Issue, Part A (Pure and Applied Science): 189-202.

9. Al-Qayim, B., Hussein, S., Qader, F., Al- Hakari, S., Shukor, B., Sardar, Z., Ahmed, D. and Abdullah, H., 2016. Integrated Stratigraphic study of the Cretaceous Petroleum -potential succession, Sulaimani Area, Kurdistan, Iraq. J of Zankoy Sulaimani, part-A, special issue, GeokurdistanII : 391-418.

10. Jassim, S. Z. and Buday, T., 2006. Late Tithonian - Early Turonian Megasequence AP 8 (Chapter 11) In: Jassim S Z and Goff J. C. (Eds.) Geology of Iraq. Dolin, Prauge and Moravian Museum, Brno, 124-140.

11. Al-Sharhan, A. S. and Nairn, A. E. M., 2003. Sedimentary Basins and Petroleum Geology of the Middle East, Elsevier, Amsterdam.

12. Al-Habba, Y. Q. and Abdulla M. B., 1989. A geochemical study of Hydrocarbon source rocks in northeastern Iraq. Oil and Arab Cooperation.15: 11- 25 (in Arabic).

13. El Diasty, W. Sh., El Beialy, S.Y., Mahdi, A. Q. and Peters, K. E. 2016. Geochemical characterization of source rocks and oils from northern Iraq: Insights from biomarker and stable carbon isotope investigations, Marine and Petroleum Geology Journal, 77: 1140-1162.

14. Sarraj, R. H. A and Mohialdeen, I. M. J., 2020. Sedimentology, palynofacies, and Hydrocarbon Generation potential of the Cretaceous Balambo Formation from selected sections, Zagros FoldThrust Belt, Kurdistan, NE Iraq, Arabian Journal of Geosciences, 13(13): 1-26.

15. Alavi, M. 2004. Regional Stratigraphy of the Zagros fold-thrust belt of Iran and its Proforland evolution. American J. of Science, 304: 1-20.

16. Zebari, M., 2013. Geometry and Evolution of Fold structures within the High Folded Zone: Zagros Fold- Thrust Belt, Kurdistan Region-Iraq, M.SC thesis, University of Nebraska.

17. Numan, N. M. S., 1997. Aplate tectonic scenario of the Phanerozoic succession in Iraq: Journal Geol.Soc. of Iraq, 30(2): 85-110.

18. Abdulnaby, W., 2018. Structural Geology and Neotectonics of Iraq, Northwest Zagros, Tectonic and Structural Framework of the Zagros Fold- Thrust Belt, University of Basrah, Chapter 4, Elsevier.

19. Verma, M. K., Thomas, S. A. and Al- Gailani, M., 2004. Petroleum reserves and undiscovered resources in the total Petroleum systems of Iraq: reserve growth and production implications, 
GeoArabia, 9(3): 51-74.

20. Hakimi, M. H., Abdullah, W. H., Shalaby, M. R., 2011a. Organic geochemical characteristics and depositional environments of the Jurassic shales in the Masila Basin of Eastern Yemen. GeoArabia, .16: 47-64.

21. Peters, K.E., Walters, C.C., Moldowan, J.M., 2005. The Biomarker Guide: Biomarkers and Isotopes in Petroleum Exploration and Earth History, seconded., vol. 2. Cambridge University Press, Cambridge.

22. Mohialdeen, I. M. J., Mustafa, K. A., Salih, D. A., Sephton, M. A., and Saeed, D. A., 2018. Biomarker analysis of the upper Jurassic Naokelekan and Barsarin formations in the Miran Well2, Miran oil field, Kurdistan Region, Iraq, Arabian Journal of Geosciences, 11: 1-15.

23. Peters, K. E., Cassa, M. R., 1994. Applied Source Rock Geochemistry. In Magoon, L. B. and Dow, W. G. (eds.), 1994. The petroleum system from source to trap. AAPG Memoir, 60: 93-120.

24. Hunt, J. M., 1979. Petroleum geochemistry and geology, 1st ed. San Francisco: Freeman, 743p.

25. Powell, T.G. and Mc Kirdy, D.M., 1973. Relationship between ratios of Pristane To phytane, crude oil composition and geological environment in Australia, Nature, 243: 37-39.

26. Bray, E. E. and Evans, E.D. 1961. Distribution of n-paraffins as a clue to recognition of source beds. Geochimicha et Cosmochimicha. Acta, 22: 2-15.

27. Lui, L. and Lee, Y. J. 2004. Geochemistry of source rocks in the Lower Tertiary Nadu Formation, Eastern Depression of the Baise Basin, Guangxi Province, China, Journal of petroleum Science and Engineering, 41: 135-157.

28. Escobar, M., Marquez, G., Inciarti, S., Rojas, J., Esteves, I., and Malandrino, G. 2011. The organic geochemistry of oil seeps from the Sierra dePerja eastern foothills. Lake Maracaibo basin, Venezuela, Org.Geochem. 42: 727-738.

29. Mohialdeen, I .M. J., Hakimi, M. H., and Al- Bayati, F.M, 2013, Geochemical and petrographic Characterization of late Jurassic-Early Cretaceous Chia Gara Formation in Northern Iraq. paleoenvironment and oil- generation potential, J Marine and Petroleum Geology. 43: 166-177.

30. Peters, K. E. and Moldowan, J. M. 1993. The Biomarker Guide: Interpreting molecular fossils in: Petroleum and Ancient Sediments. $1^{\text {st }}$ ed. Prentice Hall: Upper Saddle, 363 p.

31. Osuji, L. C. and Antia, B. C. 2005. Geochemical Implication of some chemical Fossils and Indicators of Petroleum Source Rocks, AAPL Journal, Sci. Environment Mgt. 9(1): 45-49.

32. Shanmugam, G. 1985. Significance of coniferous rainforests and related organic matter in generating commercial quantities of oil, Gipps- Land Basin. American Association of Petroleum Geologists Bulletin, 69: 1241-1254

33. De Grande, S. M. B., Aquino Neto, F. R. and Mello, M. R., 1993. Extended tricyclic terpanes in sediments and petroleum, organic geochemistry, 20: 1039-1047.

34. Waples, D. W., Machihara, T. 1991. Biomarkers for geologists: A practical guide to the application of steranes and triterpanes in petroleum geology: AAPG Meth. Exp.9.

35. Rinna, J., Rulkotter, J., Stein, R. 1996. Hydrocarbons as indicators for provenance and thermal history of organic matter in Late Cenozoic sediments from Hole 909C, frame Strait: proceedings of the Ocean Drilling program. Scientific Results, 151: 407-414.

36. Riboulleau, A., Schnyder, J., Riquier, 1. Lefebvre, V., Baudin, F. and Deconinick, J. F. 2007. Environmental change during the Early Cretaceous in the Purbeck-type Durlston Bay section (Dorset, Southern England): A biomarker approach, organic Geochemistry Journal, 38: 18041823.

37. Tang, Y., Li, M., Zhu, Q., He, D., Jiang, X., Xiao, H., Shan, J., Kang, W., Leng, J. and Wang, W., 2019. Geochemical characteristics and origin of hydrocarbons in the Mesoproterozoic reservoirs in the Liaoxi Depression, NE China, Energy Exploration and Exploitation, 0(0): 1-15.

38. Tissot, B. P. and Welte, D. H. 1984. Petroleum Formation and Occurrence, $2^{\text {nd }}$ ed. Springer Verling, $699 \mathrm{p}$.

39. Czochanska, Z., Gilbert, T. D., Philp, R. P, Sheppard, C.M., Weston, R. J., Wood, T. A., Woolhouse, A.D. 1988. Geochemical application of sterane and triterpane biomarkers to a description of oils From the Taranaki Basin in New Zealand. Organic Geochemistry, 12: 123135.

40. Moldowan, J.M., Seifert, W. K., Gallegos, E. J., 1985.Relationship between Petroleum Compositions and depositional environment of Petroleum source rocks, American Association 
Pet Geol. Bull, 69: 1255-1268.

41. Ekweozer, C. M., Okogun, J. I., Ekong, D. E. U. and Maxwell, J. R., 1979. Preliminary organic geochemical studies of samples from the Niger Delta (Nigeria). I. analyses of crude oils for triterpanes. Chemical Geology, 27: 11-28.

42. Moldowan, J. M., Dahl, J., Huizinga, B. J., Fago, F. J., Peakman, T. M. and Taylor, D. W., 1994. The Molecular Fossil Record of Oleanane and its relation to Angiosperms, Science, 265 (5173): 768-771.

43. Seifert, W. K. and Moldowan, J. M. 1978. Application of steranes, terpanes and monoaromatic to the maturation, migration and source of crude oils. Geochimica et Cosmochimica Acta,. 42: 7792.

44. Mohialdeen, I. M. J., Hakimi, M.H. and Al-Beyati, F. M., 2105. Biomarker characteristics of Certain crude oils and the oil-source rock correlation for the Kurdistan oilfields, Northern Iraq, Arabian Journal of Geosciences, 8: 507-523.

45. Seifert, W. K., Moldowan, J. M., 1986. Use of biological markers in petroleum exploration. In: Johns, R. B. Ed.. vol. 24. Amsterdam: Methods in Geochemistry and Geophysics Book Series: 261-90.

46. Seifert, W. K., Moldowan, J. M., 1980. The effect of thermal stress on source-rock quality as measured by hopane stereochemistry. Phys. Chem. Earth, 12: 229-237.

47. Isaksen, G. H. 2004.Central North Sea hydrocarbon systems: Generation,migration, Entrapment and thermal degradation of oil and gas, The American Association of Pertroleum Geologists Bulletin, 8(11): 1545-1572. 